\title{
Iamblichus' Egyptian Neoplatonic Theology in De Mysteriis
}

\author{
Dennis C. Clark \\ 2133 Shy Bear Way NW, Issaquah, Washington 98027, USA \\ dioklerikos@comcast.net
}

\begin{abstract}
In De Mysteriis VIII Iamblichus gives two orderings of first principles, one in purely Neoplatonic terms drawn from his own philosophical system, and the other in the form of several Egyptian gods, glossed with Neoplatonic language again taken from his own system. The first ordering or taxis includes the Simple One and the One Existent, two of the elements of Iamblichus' realm of the One. The second taxis includes the Egyptian $(\mathrm{H})$ eikton, which has now been identified with the god of magic, Heka, glossed as the One Existent. The Egyptian god Kmeph is also a member of this taxis, and is the Egyptian Kematef, a god of creation associated with the solar Amun-Re. Iamblichus refers to this god also as the Hegemon of the celestial gods, which should be equated to Helios, specifically the noeric Helios as described by Julian in his Hymn to Helios. Iamblichus describes Kmeph as an "intellect knowing himself", and so the noeric Kmeph/Helios should also be seen as the Paternal Demiurgic Zeus, explicitly described also by Proclus as an intellect knowing himself. This notion of a self-thinking intellect may offer a solution to the problematic formulation by Proclus in his Timaeus commentary of Iamblichus' view of the Demiurgy encompassing all the noeric realm. The identification of Kmeph as the noeric Helios now also allows the first direct parallels to de Mysteriis to be found in extant Hermetica. In addition it can be inferred from the specific Neoplatonic terminology employed that the noetic Father of Demiurges, Kronos, appears, as well as the secondary Demiurgic triad of Zeus, Poseidon, and Pluto, in the forms of the Egyptian Amun, Ptah, and Osiris, thus raising the question that much of the theology documented only in Proclus might appear already to have been established by Iamblichus.
\end{abstract}

\section{Keywords}

Iamblichus, Neoplatonic One, De Mysteriis, Egyptian religion, Kmeph 
Iamblichus in Book VIII of his defense of theurgy commonly called De Mysteriis offers two hierarchies of first principles in response to Porphyry's questions concerning how the Egyptians conceived these fundamental matters in their religion. ${ }^{1}$ The first hierarchy is presented in philosophical terms, and the second is defined by names of divinities, some of which clearly correspond to known Egyptian gods and others whose identities have been problematic at least since Ficino's time, though there is no doubt Iamblichus intended them to be taken as Egyptian. Can the philosophical characteristics of the individual levels of these hierarchies be determined and the gods associated with them be safely identified? Is Iamblichus' ranking of specific Egyptian gods consistent with their otherwise known character and functions as figures of Egyptian religion, and is there any reasonable correspondence between those functions and what is known of his philosophical doctrines? A close reading of de Myst. VIII and relevant passages from other later Neoplatonists in conjunction with related scholarly work, some very recent, may provide tentative proposals to answer these questions, if not a completely definitive set of solutions to the problems raised by this text.

In de Myst. VIII Iamblichus in the persona of Abamon the Egyptian seeks to answer Porphyry's questions about the nature of Egyptian religion, what its first cause is, whether that cause is material or not, is of intellect or not, or is from one or many. Iamblichus' response takes the form of what appears as his interpretation of views held by many unnamed Egyptian priests, some according to him of contemporary date, but including also doctrines of Hermes-Thoth himself. ${ }^{2}$ Iamblichus proceeds to give two explanations of first principles; in the first he expounds what appears in comparison with evidence from other of his works to be known doctrines of his own Neoplatonist philosophy. At the end of this passage he indirectly attributes his exposition to Hermes-Thoth by saying that "थ̈

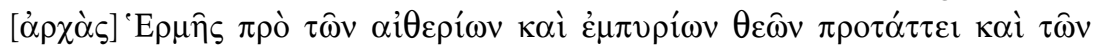

\footnotetext{
1) The more proper name of the work is actually Response of Abamon, his professor, to the Letter addressed by Porphyry to Anebo, as pointed out by H.D. Saffrey (1971) 227, but following custom all references here will be to de Mysteriis (hereafter de Myst.) in the edition and translation of E.C. Clarke, J. Dillon, and J.P. Hershbell (2003), which reproduces the text of É. des Places (1966).

2) On the syncretism of Hermes and Thoth, E.C. Clarke, J. Dillon, and J.P. Hershbell (2003) 5 and xxxi-xxxii, as well as G. Fowden (1993) 22-24 and 201-202.
} 
$\dot{\varepsilon} \pi$ oupoví $\omega v$." The second explanation is given as an alternative taxis also set forth by Hermes-Thoth, and is couched in divine terms, comprised of explicitly named Egyptian gods at the various levels, but with each glossed in what is clearly Neoplatonist language, describing their places in the taxonomy presented, as well as their functions:

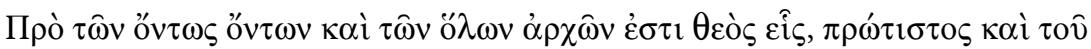

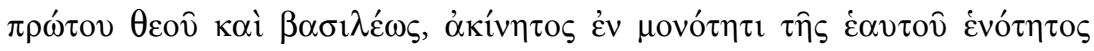

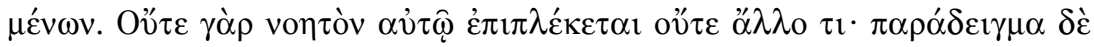

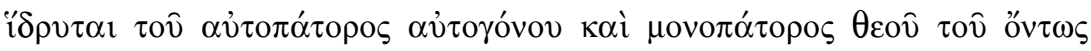

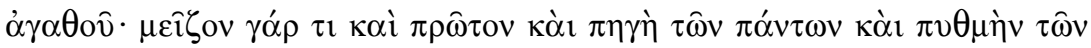

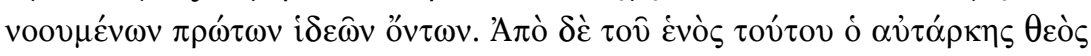

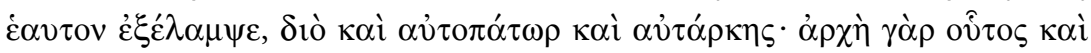

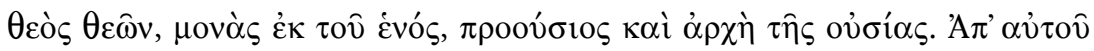

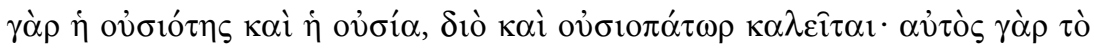

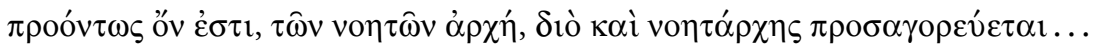

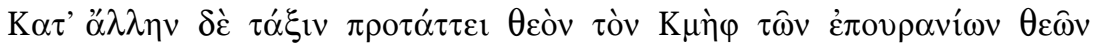

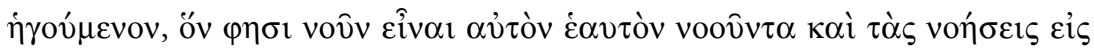

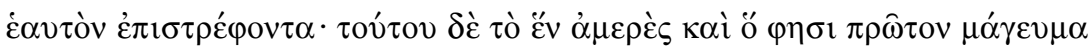

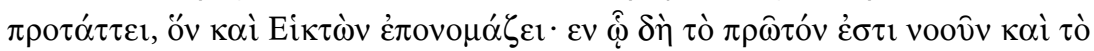

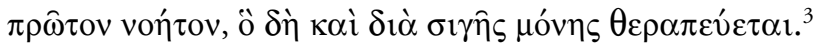

3) "Prior to the true beings and to the universal principles there is the one god, prior cause even of the first god and king, remaining unmoved in the singularity of his own unity. For no object of intellection is linked to him, nor anything else. He is established as a paradigm for the self-fathering, self-generating and only-fathered God who is true Good; for it is something greater, and primary, and fount of all things, and basic root of all the first objects of intellection, which are the forms. From this One there has autonomously shone forth the self-sufficient god, for which reason he is termed 'father of himself' and 'principle of himself'; for he is first principle and god of gods, a monad springing from the One, pre-essential and first principle of essence. For from him springs essentiality and essence, for which reason he is termed 'father of essence'; he himself is pre-essential being, the first principle of the intelligible realm, for which reason he is termed 'principle of intellection'... Following another system of ordering, he [Hermes-Thoth] gives first rank to Kmeph, the leader of the celestial gods, whom he declares to be an intellect thinking himself, and turning his thoughts towards himself; but prior to him he places the indivisible One and what he calls the "first act of magic" which he calls Heikton. It is in him that there resides the primal intelligising element and the primal object of intellection, which, it must be specified, is worshipped by means of silence alone." Translation and text, somewhat modified, E.C. Clarke, J. Dillon, and J.P. Hershbell (2003) 307-311. 
"Scholars have not found it easy to make sense of all this. There is some traditional Egyptian material (though not such as was unavailable in the Greek literature on the subject), jumbled together with relatively late Greek philosophical speculation, and little clue as to how it all fits together." ${ }^{4}$ At first reading the second taxis of Hermes-Thoth does appear especially daunting, for a number of reasons, including textual difficulties related to the names of the Egyptian gods, questions as to why Iamblichus chose these specific gods and what relevance, if any, they have to the rest of his philosophy, to say nothing about the likelihood that a Neoplatonist philosopher from Syria in the late third century would have any reliable knowledge at all about ancient Egyptian religion. Before addressing these issues, an explication of the more straightforward first part of his response to Porphyry is in order.

Even though many of Iamblichus' works have been lost, fortunately at least a basic understanding of his doctrine of first principles can be gained from references to his writings in other later Neoplatonists, such as Proclus and Damascius, although there are still areas of his entire system not yet fully understood nor likely ever to be totally recovered. In view of this loss, the passage above describing the first theological taxis in fact should be appreciated all the more, since it is a major extant instance of Iamblichus' thought in his own words, even if given as teachings of Hermes-Thoth. John Dillon has reconstructed the elements of Iamblichus' system, including, particularly of interest here, the highest levels, which appear to be the subject of this first part of his response to Porphyry's questions on Egyptian religion. ${ }^{5}$ In Dillon's reconstruction, Iamblichus places at the apex-in what would correspond in Plotinus to the hypostasis of the One$\pi \alpha v \tau \varepsilon \lambda \omega \omega_{\varsigma} \alpha \rho_{\rho} \rho \eta \tau o v$, an Ineffable First One, completely aloof and apart from all, even Being itself, followed then by the Simple One ( $\tau$ ò $\dot{\alpha} \pi \lambda \hat{\omega} \varsigma \varepsilon^{2} v$ ),

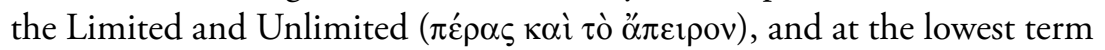
of this first hypostasis (but also appearing in true Iamblichean fashion as the highest moment of the next hypostasis below, that of Nous the noeticnoeric realm), the One Existent ( $\tau$ ò ěv öv). Commentators on de Myst. VIII.2 agree that the elements expressed in the first taxis do correspond

4) G. Fowden (1993) 138.

5) J. Dillon (1973) 29-39, and J. Dillon (1987) 880-890. Other useful discussions of Iamblichus' first principles especially as reflected in de Myst. VIII include É. des Places (1975) 74-77, and P. Hadot (1968) 96-98, and A.R. Sodano (1984) 366-68. 
with levels within Iamblichus' hypostasis of the One, though they do not all agree as to exactly which moments are represented in the taxis, and given the nature of the text a completely certain identification is perhaps not possible. The first mentioned "one god, prior cause even of the first god and king remaining unmoved" has been taken alternatively as the Ineffable First One or the Simple One, but John Finamore has stressed the importance of not interpreting this "one god, prior cause" as the Ineffable First One, because Iamblichus is giving an explication here of a Hermetic

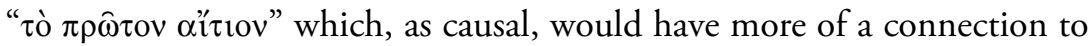
the following elements than the absolute aloofness of the Ineffable First One would intrinsically allow. ${ }^{6}$ The description "no object of intellection is linked to him, or anything else" certainly at first hearing sounds rather more fitting for the Ineffable First One, but in actuality the same could be said of the Simple One as well, since in the first hypostasis only the lowest element, the One Existent, in its role as the highest moment of the hypostasis of Nous, serves as the "object of intellection." Also it might be added that the second element in this taxis, "the self-fathered god," is described as "shining forth" from the first element, the "one god, prior cause" which in addition is characterized as "One" ("A

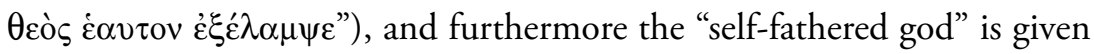

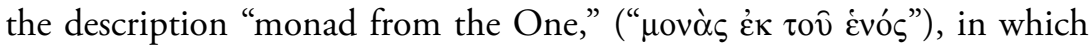
"One" refers to the preceding element of this taxis, the "one god, prior cause," so that it can be inferred that there is a consecutive relationship between the two with nothing intervening. Thus, from the fact that it will be seen that the second element of this taxis most likely corresponds to the One Existent, there is more evidence that the first element must be rather the Simple One than the Ineffable One, since the Simple One directly precedes the One Existent in Damascius' report of Iamblichus' schema. Moreover Iamblichus refers here to the first element as serving as the $\pi \alpha \rho \alpha \dot{\delta} \delta \varepsilon \gamma \mu \alpha$ for the second element. The context makes it clear he does not mean the term in the special sense of the Paradigm as used by Plato in the

6) E.C. Clarke, J. Dillon, and J.P. Hershbell (2003) 307 takes this figure to be either the Ineffable First One or the Simple One, but previously Dillon had identified it "more or less" with the Ineffable First One but also makes the important caution that these concepts in de Myst. VIII are not necessarily truly Hermetic and might not "represent Iamblichus' own doctrine in its fullest complexity, even at an earlier stage of his development", J. Dillon (1987) 884-85. Finamore's distinction is to be found in J. Finamore (2000) 250. 
Timaeus, rather as the more general meaning of a paradigm or model; but such a function does rather suggest that this moment is the moment of the hypostasis "in participation." This classification concerning participation is a part of Iamblichus' developed philosophy, expanding on the simpler view of each hypostasis in Plotinus' system, so that the hypostasis is now also seen as containing a triad of elements termed $\alpha \mu \varepsilon \dot{\theta} \theta \varepsilon \kappa \tau о \varsigma-\mu \varepsilon \tau \varepsilon \chi o ́ \mu \varepsilon v o \varsigma-$ $\kappa \alpha \tau \grave{\alpha} \mu \varepsilon \dot{\varepsilon} \varepsilon \varepsilon \xi_{i v}{ }^{7}$ If Iamblichus' characterization of the first element as paradigmatic for forming the next element down can be taken as another way of calling it "in participation" ( $\mu \varepsilon \tau \varepsilon \chi 0$ óvvos), where the second element of

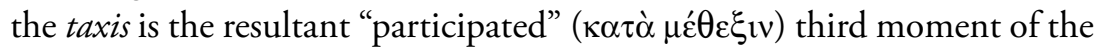
hypostasis formed using the first element as "paradigm", then there is possibly more proof that the first element, the "one god, prior cause," is the Simple One which precedes the One Existent. At any rate, however persuasive these other additional interpretations offered here may or may not be, Finamore's distinction is by itself an important one, but given the sparse original evidence for Iamblichus' system and the fact that he is here, after all, avowedly representing Egyptian and Hermetic doctrines, however much expressed in his own Neoplatonic terms and not necessarily in an exhaustive or comprehensive manner, there is certainly still room for doubt as to the exact correspondence of any of these elements to those in his own hierarchy as defined by Damascius. ${ }^{8}$

The second element of the first taxis, the "first god and king" and "first principle and god of gods", presents fewer problems of identification and appears with some certainty to scholars to be, as mentioned above, the One Existent, most especially since its relation to the noetic-noeric realm, denoted as the "first principle of the intelligible realm" and "principle of intellection", is explicitly referred to in its description. ${ }^{9}$ The appearance of the epithets $\alpha \dot{\tau} \tau 0 \pi \alpha \dot{\tau} \tau \rho \rho$ and $\alpha \dot{\tau} \tau \alpha \dot{\rho} \rho \eta \varsigma$, however, is of special interest. These apparently self-generating entities are also found at correspondingly high levels in other contemporary systems, such as various Gnostic beliefs, and, more pertinently, Porphyry's own characterization of the second god in his

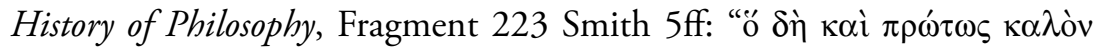

\footnotetext{
7) J. Dillon (1987) 885.

${ }^{8)}$ In interpreting this passage and the rest of de Myst. VIII one also does well to take into account Dillon's view that "Iamblichus is professing to interpret Egyptian theology here, not to give his own doctrine", J. Dillon (1987) 885.

9) E.C. Clarke, J. Dillon, and J.P. Hershbell (2003) 309 n 405.
} 


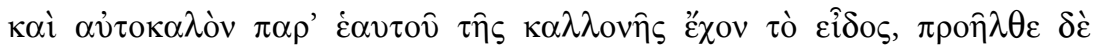

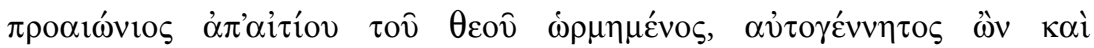

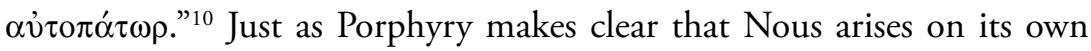
without any direct connection to the One, so Iamblichus distinguishes the One Existent here as self-generating, using exactly the same language as Porphyry. ${ }^{11}$ Thus it is likely that Iamblichus has chosen these epithets quite purposefully in order to cast his argument in the same terminology employed by Porphyry himself to declare that the Egyptian system at this level is not at all strictly material, rather is noeric in the same way that the hypostasis of Nous is, emphasizing the equally self-generating nature of this element of the taxis, just like Porphyry's second god from Fragment 223.

Iamblichus thus limits himself in this first taxis to only two elements of the four delineated by Damascius; clearly he does not include mention of the Limited and Unlimited, and perhaps more significantly most likely also omits the Ineffable First One. The reason for this approach is not readily apparent. Is it perhaps possible that Iamblichus has in mind two elements represented elsewhere in more detail in some Hermetic work familiar to him but no longer extant, and also well known to Porphyry, well enough in fact that Iamblichus can so elliptically reproduce the

10) This concept of self-generating principles is much in evidence in contemporary systems other than Neoplatonism. Chaldaean Oracle 39 offers one example; see Majercik's commentary ad loc, R. Majercik, (1989) 158-59, where she repeats Whittaker's assertion that this notion may actually have arisen from oracular literature such as the Chaldaean Oracles, in J. Whittaker (1980) 176-189, especially 177 where Whittaker discusses Porphyry 223F.

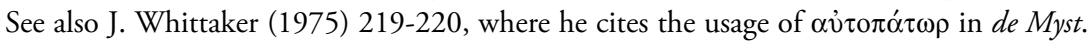
VIII.2 and Porphyry 223F. Jean-Pierre Mahé also cites Iamblichus here in comparison with similar instances of self-generating principles found in J.-P. Mahé (1978) 50-51.

11) John Dillon has noted the further significance of the appearance of a self-generated secondary god here in de Myst. VIII.2 in connection with a passage in Proclus' in Parm. VII.1149, 26ff, where Proclus criticizes those Platonists who would also characterize the One itself as self-generated, in J. Dillon (1988) 36-39. Proclus praises an unnamed earlier Platonist, most likely Iamblichus, in Dillon's view, who, rightly according to Proclus, denies self-generation to the One but confirms it, as in de Myst. VIII.2, to the next level of entities, who interestingly enough, like the "self-fathered god" in the first taxis also "shine forth" from the One. Proclus, rather anachronistically, as Dillon points out, includes Plotinus in his criticism of those Platonists seeing the One as self-generative. For the latest analysis of the self-generation and pre-eternal nature of Nous put forth by Porphry in 223F, especially in relation to Plotinus, see now S.K. Strange (2007) 28-31. 
elements here, glossed in Neoplatonic terms that would be familiar to Porphyry, in a strictly allusive manner that might well have signified more to either of them than a modern reader? At the end of this passage Iamblichus

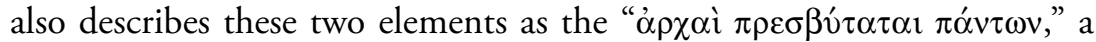
characterization which fairly clearly represents them as the two highest principles, though he has not included here any mention of what would be the highest principle in his own philosophy, the Ineffable One. There appears then to be an inconsistency or at least incompleteness in the hierarchy outlined here in comparison with that laid out by Damascius. But Iamblichus is concerned with Egyptian religion here, which he may have considered simply not to have figures corresponding to these two missing elements of his system, or he may rather be glossing a Hermetic ordering in his own Neoplatonic terms which had no element analogous to the Ineffable First One and the Limited and Unlimited, in which case the two elements of this first taxis are in that Hermetic context " $\alpha \rho \chi \alpha i ̀ ~ \pi \rho \varepsilon \sigma \beta \hat{\tau} \tau \alpha \tau \alpha \iota "$ after all; not having the original text or texts used as his source makes it impossible to determine this issue for certain. ${ }^{12}$ Certainly Iamblichus' emphasis on elements from the highest levels of his system makes it very clear nevertheless that he is denying to Porphyry the contention that the Egyptians viewed the universe only in purely material terms. At any rate, it will be seen that in the second taxis several more elements are offered to the reader, so that not even a simple numerical consistency can be drawn from the first to the second taxis. Even though Iamblichus' stated intent here is to represent Hermes-Thoth on this subject, in the first taxis he does not use any overtly Egyptian terms nor, interestingly enough, terms clearly within current knowledge identifiable as specifically Hermetic. Rather, as has been shown, he employs more general philosophical language with Neoplatonic values consistent with what is known of his own system, with

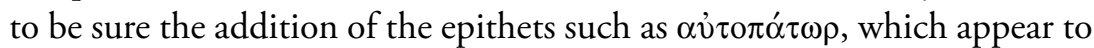

12) É. des Places (1975) 77, points out that we have to admit that the hierarchy in the first taxis does not conform to the full system delineated by Damascius. Another principle, however, may be operative here. Iamblichus may simply be intentionally selective in how much he chooses to disclose of his philosophy, depending on the nature of his audience and type of treatise under consideration; Dillon has advanced this notion more than once, including in J. Dillon (1999) 105. Or perhaps the notion that not all readers of a given text are advanced enough in the "mysteries" of Neoplatonist theology is at play here, so that some of the highest principles should not be revealed. 
be drawn from the common sources feeding also the Chaldaean Oracles and Gnostic systems, all in the realm of the "Platonic Underworld."13 But by deliberately casting his first response to Porphyry's query on the nature of Egyptian religion in so abstract a manner, without giving any specific Egyptian elements, he appears to make it clear he thinks that the Egyptian system (or perhaps an Egypto-Hermetic one) is already firmly in the Neoplatonist orbit, or at least that he is of the opinion, apparently contrary to Porphyry, that it can be brought in and as readily synthesized to Neoplatonist thought as had been the Chaldean Oracles, and as would later the greater part of Hellenic Olympian theology itself be treated in the works of later Neoplatonists such as Proclus.

In the second taxis Iamblichus again refers to Hermes-Thoth as his source, but now gives a hierarchy specifically cast in terms of Egyptian gods. His source is probably best assumed to be some lost Hermetic work, since as with the first taxis no extant specimen of the Hermetica contains this particular representation of Egyptian religion interpreted in such a philosophical fashion. Though not provable given the existing textual evidence, there is at least the likelihood that some original product of Egyptian wisdom literature, or some other work, likely in the tradition of the Book of Thoth, provides the source from which these ideas were formed in the Hermetica, perhaps in more than one step via intermediary texts in either late Egyptian and Greek. Iamblichus himself states in de Myst.VIII.4 that he believed the texts to be translations into Greek from Egyptian, and taking them as a starting point, he reinterprets them at higher, more Neoplatonist level than had been achieved by earlier interpreters of Egyptian religion, such as Chaeremon, cited in fact by name by Iamblichus, in order to formulate his response to Porphyry. ${ }^{14}$ Iamblichus specifically also

\footnotetext{
13) Term coined and the phenomenon surveyed by J. Dillon (1996) $384 f f$.

14) For the concept that the Hermetica contain texts influenced at some remove from the Book of Thoth or its like, see now the important new edition of R. Jasnow and K.-Th. Zauzich (2005) 71, and for their comments on the existence of other Greek translations of Egyptian religious texts in circulation in the Roman period, 66. While there are no strict verbal parallels to be found in the Book of Thoth and any extant Hermetic text, they nevertheless conclude that the "similarities between the Book of Thoth and the Hermetic Corpus are of format, phraseology, and, to some extent, content." (71). Their introductory essay "Hermetic and Greek Interaction as reflected in the Book of Thoth", 65-71, examines judiciously and in detail the parallels and likelihood of historical influence of this and other late Egyptian texts on the Hermetica.
} 
remarks that Porphyry had formed his questions from reading these same apparently Hermetic texts. ${ }^{15}$ Be that as it may, Iamblichus in de Myst. VIII chooses to include five Egyptian gods in this hierarchy: Kmeph, Eikton, Amon, Ptah, and Osiris. ${ }^{16}$ Exactly why these five gods are chosen for explication is certainly not at first reading intuitively obvious from any perspective, though it is easy enough to observe that in any context Amon, Ptah, and Osiris are all major gods and all central to various and quite ancient creation myths among the Egyptians. But what of the other two, Kmeph and Eikton, whose names are not as familiar? Though Iamblichus discusses Kmeph first in the sequence of his exposition, he claims that Eikton is higher in rank. The name "Eikton", an apparently Hellenized form, does not appear to represent any known Egyptian deity; exactly to which god is Iamblichus referring here? A number of suggestions have been made by scholars for the possible identity of Eikton, but one very recent attempt likely offers the most satisfactory solution to this problem. ${ }^{17}$ Elsa Oréal has identified Eikton as Heka, the Egyptian god of magic, and for this reason the aspirate may well be added to render the name more properly, if she is correct, as Heikton. ${ }^{18}$ Acceptance of Heka as the original Egyptian referent for Heikton also has the felicitous corollary result that the lectio difficilior

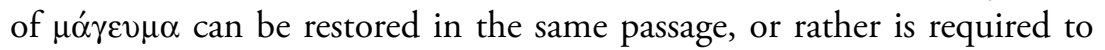
be by the new context, so that a textual difficulty first raised by Marsilio Ficino is resolved which previously had never really found any satisfactory

15) Iamblichus refers to Chaeremon at VIII.4.266.1 specifically as one of these earlier philosophers writing about Egypt. He was also a Stoic and many of his fragments are in fact preserved by Porphyry; perhaps Porphyry was influenced in his materialistic view of Egyptian religion by his reading of the Stoic Chaeremon. Iamblichus does not acknowledge Porphyry's familiarity with Chaeremon, and it is possible of course that he was not even aware of it, but the mention of the Stoic in this context of his response to Porphyry on this very subject is at least suggestive that his reference to Chaeremon was meant as a personal reminder to Porphyry in this regard.

16) On the emendation by Scott of the MSS readings of $\mathrm{E} \mu \eta \varphi$ to K $\mu \eta \varphi$, E.C. Clarke, J. Dillon, and J.P. Hershbell (2003) 309 n407 and xliv-xlv.

17) A.R. Sodano (1984) 368, summarizes a number of the suggested identifications, to which may be added two very early attempts discussed by the Egyptologist E. Oréal (2003) 281, and E.C. Clarke, J. Dillon, and J.P. Hershbell (2003) 311 and xlv, also put forth the idea that Eikton could be the Egyptian Irta or Ihy.

18) E. Oréal (2003) 281-82. 
resolution. ${ }^{19}$ Furthermore, the term $\mu \alpha \gamma_{\varepsilon \varepsilon} \mu \alpha$ is actually quite appropriate to describe the various aspects of magic represented in the Egyptian tradition by Heka, for the Egyptian word can refer not only to the god himself but also the act of magic as well as the intrinsic power of magic as a cosmo-

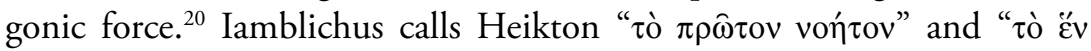
$\dot{\alpha} \mu \varepsilon \rho \grave{\varepsilon} \varsigma$ ", which fairly clearly point, as he continues to offer Neoplatonic glosses, to the One Existent, the third moment of the first hypostasis, viewed as the first moment of the second hypostasis, the first object of thought, apparently then identical to the second element of the first taxis discussed above. ${ }^{21}$ Curiously enough, to the Egyptians, at a date far in advance of Iamblichus, Heka occupied a similar position as can be determined from Heka's own reported words in one of the Coffin Texts: "O noble one who are before the Lord of the universe ("the All"), behold, I have come before you. Respect me with accordance with what you know.

19) On Gale's conjecture of $\mu \alpha i$ ív $\mu \alpha$ which has been widely accepted since his time, E.C. Clarke, J. Dillon, and J.P. Hershbell (2003) 311n409 and xlv. Ficino had conjectured $\pi \alpha \rho \alpha ́ \delta \varepsilon \imath \gamma \mu \alpha$.

20) As thoroughly discussed in the most recent explication of Heka in Egyptian religion, R.K. Ritner (1993) 14-28.

21) For the identification with the One Existent, E.C. Clarke, J. Dillon, and J.P. Hershbell

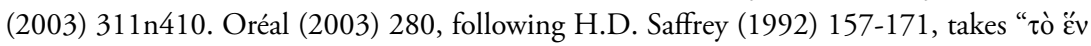
$\dot{\alpha} \mu \varepsilon \rho \dot{\varepsilon} \varsigma$ " as a completely separate entity on its own level in the hierarchy of the second taxis. No other commentator has interpreted Iamblichus here in this way, and in his article Saffrey does not actually offer any specific argument as proof for this interpretation. If it is indeed to be taken as a separate entity, it would then be the only one in this passage that does not have its own Egyptian god assigned to it, and in fact Iamblichus otherwise consistently presents an Egyptian god in this taxis and then explicates it via some Neoplatonic gloss, rather then merely giving a Neoplatonic term by itself, as would appear to occur in Saffrey's reading (though it will be seen below that later in Book VIII Iamblichus does introduce a Neoplatonic entity without giving it an Egyptian name). But the Greek is ambiguous and certainly can be read in this way, at least if the interpretation is limited just to the sentence by itself. Determining which reading is correct really comes down to not

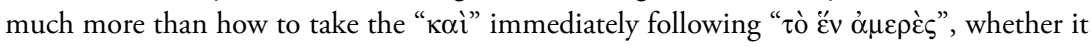
is intended as linking expressions in apposition to Heikton, or as conjoining another clause containing the expression " $\tau \grave{o}$ Ěv $\dot{\alpha} \mu \varepsilon \rho \grave{\varepsilon} \varsigma$ ” perhaps also in a separate apposition to another, unexpressed noun representing some other entity. Certainly the terseness of Iamblichus' style here and the subject matter do not aid in interpreting this passage. If indeed it is another entity being set forth here, then the most likely candidate would be the Simple One, which is included in the first taxis as discussed above, given its designation as "one without parts" and the fact that already Heikton is definitely to be taken as the One Existent. 
I am he whom the Unique Lord made before two things ("duality") had yet come into being in this land by his sending forth his unique eye, when he was alone, by the going forth from his mouth... when he put $\mathrm{Hu}$ ("Logos") upon his mouth... I am indeed the son of Him who gave birth to the universe ("the All"), who was born before his mother yet existed... I have come that I might take my seat and that I might receive my dignity, for to me belonged the universe before you gods had yet come into being. Descend, you who have come in the end. I am Heka."22 The phrase "born before his mother existed" could fairly easily be interpreted to mean that Heka, as the One Existent, which Heka is described by Iamblichus to be here, is also $\alpha \dot{\theta} \theta v \pi$ ó $\tau \alpha \tau o \varsigma$. But another Coffin Spell explicitly describes him in just those terms, as well as declaring him to be a central, primordial force in the act of cosmogony: "His powers put fear into the gods who came into being after him, his myriad of spirits is within his mouth. It was Heka who came into being of himself,... [and] who created the mountains and knit the firmament together." ${ }^{23}$ Heka in addition plays an important role in the daily reenactment of creation that the Egyptians represented in the daily and nightly voyage of the barque of the sun god Re; he joins $\mathrm{Hu}$ and Sia on the vessel, "invoking the separation of heaven and earth" and performs as a guardian of the barque in its nightly passage through the Duat, or Underworld, to defeat the Apophis serpent and the chaos he represents. $^{24}$

22) R.K. Ritner (1993) 17.

23) Ibid.

24) R.K. Ritner (1993) 18. Sia represents Perception in the Egyptian tradition. Significant for the identification with Heka is also the fact that the god continued to be worshipped well into the Roman period, including at Esna as late as at least the second century; see also R.K. Ritner (1995) 3333-3379, especially 3353-3354 on Heka, and E. Oréal (2003) 282283, where she discusses the relevant texts from Esna, published by S. Sauneron (1962) 211-212. E. Oréal (2003) points out also that, regardless of how the transmission to Iamblichus occurred, the place he affords Heka in his system is fully consistent with that occupied by the god in the Egyptian cosmogony, and that "la mention de Héka chez Jamblique n'est ni un simple element decoratif” (284). One possible source of physical exhange could have been supplied by the still fully operating Egyptian temple archives themselves, as discussed by R.K. Ritner (1995) 3356, where he also details the fascinating story of the Greek physician in training, Thessalus, who came to Thebes in Upper Egypt to further his philosophical studies and approached Egyptian priests there in the hopes of arranging a real face to face divine encounter with Aesclepius-Imhotep. The extant text describing Thessalus' 
Though it is certainly impossible to know whether Iamblichus had access to any texts, Hermetic or otherwise, describing Heka in these terms, it is nonetheless remarkably striking how consistent the Egyptian conception is with the one given by Iamblichus in Neoplatonic terms, especially concerning his being, on the one hand, "whom the Unique Lord made

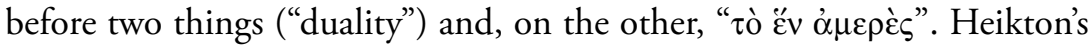
position as the One Existent is totally consonant with the Egyptian view of Heka, who is $\alpha \dot{v} \theta v \pi$ ó $\sigma \tau \alpha \tau o \zeta$ and comes to exist before all the other gods, as would the One Existent. It must also be said that the inclusion of the Egyptian god of magic so high in any taxonomy of first principles in a work seeking to defend theurgy is a singularly appropriate choice; just as Iamblichus is at pains in this work to argue to Porphyry that theurgy is in no way equivalent to magic used for base and merely personal purposes, Heka, as can be seen from the Coffin Texts, represents magic of a higher order, crucial to the application of the power of Atum-Re in the act of creating the cosmos. ${ }^{25}$ Heka appears as a power even before the first utterance of the Logos (the Egyptian $\mathrm{Hu}$ ), and it is of note that Iamblichus stipulates that Heikton must be worshipped only in silence. As the first thought he is before all speech, just as Heka comes before $\mathrm{Hu}$, the first utterance. There also perhaps might be some reflex here of the notion that Heka viewed in his role as magic effected through spoken charms, must not be spoken of aloud in prayer, as even his name would itself have great power. ${ }^{26}$ Silence before the gods is an ancient Egyptian notion, and there are numerous instances of the observance of silence in reverence of the highest powers in Gnostic and Chaldaean contexts. ${ }^{27}$ Another example of

adventures and his session with the god in Thebes is edited by A.J. Festugière (1967a) 141-174. R.K. Ritner (1995) 3358 also enumerates the known instances of Egyptians, well schooled in Hellenistic as well as native Egyptian traditions, traveling outside of Egypt to various locations in the Empire.

25) Note that Iamblichus does not include any mention of Atum-Re, though by setting Heikton as the One Existent, the god technically in terms of his philosophical system is not at the top of the hierarchy, so that it could be speculated that there it is hypothetically possible for Atum-Re to be "glossed" at a higher level in ranking. For more on the close relationship of Heka to Atum-Re, see H. Bonnet (2000) 301.

26) This notion derives from a personal communication from Prof. Ritner.

27) Silence at least in the most intimate relations with the god is rather a topos of Egyptian religion. "The Egyptian believer displays his faith and his devotion in quiet and calm behavior during divine service. The instructions repeatedly call for silence while offering sacrifices 
this notion is to be found, appropriately enough, in Porphyry himself, who refers to this practice among the Egyptians in his Allegory on the Cave of the Nymphs in Homer, where he claims that the Pythagoreans and wise men among the Egyptians forbade speaking when passing through doors or gates, so that they revere "i் phyry in de Abstinentia, citing Apollonius of Tyana, also emphasizes the importance of silence in regards to the worship of the highest noeric gods, since thought precedes speech and such gods are removed from physical things. ${ }^{29}$ Iamblichus elaborates no further on Heka and gives no more details than these, so there is nothing more explicit in the text itself to suggest exactly why he chose to include Heka in this taxis and at this particular level, but the fact alone of the relevancy of theurgy to the Egyptian god of magic, enhanced by the exalted and crucial role taken by Heka in the enactment of cosmogony, may be sufficient to explain his choice.

Iamblichus places Kmeph high in his hierarchy of gods in this second taxis, but lower than Heikton, and both clearly are set above the physical cosmos, in that both Kmeph and Heikton are described with functional roles concerned with the level of Nous. Kmeph is called only "an intellect thinking himself, turning his thoughts toward himself." Again, Iamblichus emphasizes to Porphyry what he sees as the non-material character of these Egyptian gods. While Heikton is unattested elsewhere in any Greek text, Kmeph on the other hand finds mention in several writers, including significantly in the writings of other Neoplatonists. In the case of Kmeph, however, the Egyptian god referred to in the Greek form of the name has been definitively established: Kematef, represented in Greek as Kvท́ $\varphi$ or

in the temple... or while engaged in activities in the necropolis, whose epithet is 'the place of the quiet.' The gods-Amon, Osiris and Sobek-Re-are 'lords of silence'. The priest whose behavior follows this pattern may take pride in being the 'possessor of balanced steps' (qb nmt.t) in the holy of holies and in not 'raising his voice"', N. Shupak (1993) 159; for this reference I thank Katherine Griffis-Greenberg of the Oriental Institute at Oxford University, communicated to me via the Yahoo ANET online discussion group. See also H. Frankfort (1948) 66, on the teachings of Amenemope concerning silence. For references on the significance of silence in the Greek tradition and chronologically nearer to Iamblichus, see E.C. Clarke, J. Dillon, and J.P. Hershbell (2003) 311n412, and on the importance of silence in Hermetic thought, G. Fowden (1993) 70.

28) Allegory on the Cave of the Nymphs 27, 15-16.

29) De Abstinentia 2,34. For an in-depth discussion of this passage and Porphyry's reinterpretation of Apollonius, see Porphyry transl. G. Clark (2000) 152-153. 


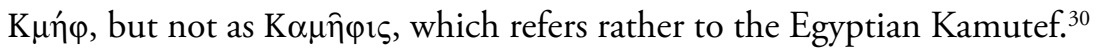
Kematef in later Egyptian religion appears normally as an epithet or as "determinative" in conjunction with Amun, and the name in Egyptian literally means "one who has completed his moment, his time." ${ }^{11}$ Kematef is seen as having a Theban provenance, as was actually noted already in Antiquity by Plutarch, but was worshipped at a number of sites in Egypt in the Ptolemaic and Roman periods, including, like Heka, at Esna, and is "ein Produkt der thebanischen Theologen der Ptolemäerzeit." ${ }^{32}$ Kematef in the form of a coiled serpent, in fact that of the Ouroboros, is associated with the instantaneous act of creation of the universe arising out of the primordial abyss of the waters of Nun; in at least one important late Egyptian religious text, the Khonsu cosmogony, inscribed on the walls of the Khonsu barque chapel within the temple complex at Karnak, Amun-Re is represented as the "great" or "noble" Ba of Kematef. ${ }^{33}$ In late Egyptian theology, for one god to be considered the Ba of another meant that it took a more physically accessible form, one which could be perceived by human senses, directly venerated and in this case perform the physical act of creation, that was in a more abstract and non-physical sense also performed by the god Kematef. ${ }^{34}$ In another divine constellation Kematef is also the

30) The definitive study thoroughly explicating the complicated issues regarding these Egyptian deities and their representations in Greek sources is H.J. Thissen (1996) 153-160, who also includes all the citations in Greek sources of Kmeph. For the proper association of Kmeph with Kematef, see 156. Thissen, an Egyptologist, offers corrections to a number of improper identifications of Kmeph and other Egyptian gods in earlier scholarly works.

31) H.J. Thissen (1996) $155 \mathrm{n} 22$, parses the Egyptian Kematef as km-3t=f, where "km" represents "die Form des Verbums $\mathrm{km}$ 'vollenden"” which can take a present or perfect tense, and translates Kematef as "der, der seinen Augenblick vollendet (hat)." See also the entry of H. Bonnet (2000) on Kematef, pp.373-74.

32) H.J. Thissen (1996) 157. The report of Plutarch is found at de Iside et Osiride 21, 359D; cf J.G. Griffiths (1970) 374 for commentary, which H.J. Thissen (1996) 157, finds sufficient and correct. On Kematef at Esna, see S. Sauneron (1962) 319.

33) For a detailed explication of Kematef in Egyptian religion, see K. Sethe (1929) 26-27. See also R.T. Rundle-Clark (1959) 50. For the inscriptions at Karnak and explanation of the relationship of Amun-Re as the Ba of Kematef, see now the important study of D. Mendel (2003) 38-39. Mendel refers in the introduction (3) to this study to a monograph dedicated solely to the examination of the divine name of Kematef currently in preparation by herself and Prof. Thissen.

34) For this concept of the Ba concept in general and as regards Amun-Re and Kematef, see also D. Mendel (2003) 25-26 and J. Assmann (2001) 178. 
father of Irta, again a serpent figure associated with creation. ${ }^{35}$ The expression "one who has completed his moment" most likely refers to a concept of time before time in the physical universe. ${ }^{36}$ By the Ptolemaic and Roman periods Amun had for centuries been associated with the supreme sun god $\mathrm{Re}$, and is actually himself one of the Ogdoad, though the Theban theology had raised him up to a higher status with Re, and by Iamblichus' time he would have been thought of clearly as a solar deity. ${ }^{37}$ As with Heka, there is no sure way of ascertaining exactly how many of these original religious aspects of Kematef that Iamblichus would have had accurate knowledge of, regardless of however long the worship and cultivation of these gods continued among Egyptians in the Roman period, but at least one thing can be said, that the image of the Ouroboros of Kematef is quite apt for the intellectual god who "turns his thoughts toward himself", and, as with Heka, the cosmogonical role of Kematef, especially appearing as a figure of instantaneous time before physical time at the moment of creation, as it were, is certainly appropriate for a god described as Kmeph is by Iamblichus at the noeric level. ${ }^{38}$

Kematef in the form of Kneph/Kmeph also occurs among Greek writers at least as early as Plutarch, in terms which echo his Egyptian characteristics,

35) For Irta see D. Mendel (2003) 26. For a summary of the main occurrences of Kematef in late period Egyptian cult sites, see H.J. Thissen (1996) 157, where he observes as a result of the god's widespread cultivation that "er verkörpert regelmässig den Urgott, den Uranfang, den Beginn der Schöpfung. Es wäre verwunderlich, wenn solche Spekulationen nicht auch Spüren in griechischen Texten hinterlassen hätten.”

36) "Die 'Vollendung des Augenblicks' ist sonst Ausdruck für die Schnelligkeit eines Geschehens. Hier wird an die Vollendung der Lebenszeit des Gottes gedacht sein, die für menschliche Begriffe unendlich gross, für ihn nur ein Augenblick bedeutete. Denn diese Schlange soll, wie es scheint, ebenso wie der in ihr verkörperte Gott Amun... einem vergangenen Zeitalter angehören und verstorben sein,” K. Sethe (1929) 26. Cf. J.G. Griffiths (1970), p.374, "Km-3t.f, 'he has completed his age', or perhaps 'he who has completed his moment', i.e. has finished his lifetime in a moment, an allusion to the serpent's swiftness." 37) "In dieser Urgestalt, in der er zum 'Vater der Väter der Achtheit' wird, dachte man $\mathrm{A}[\mathrm{mun}]$ in einer Schlange verkörpert, die als Wesen einer fernen Weltperiode Kematef 'der seine Zeit vollendet hat' hiess... So wird A[mun] in Erscheinungsformen gespalten, die sich auf drei, ja auf vier Generationen verteilen. Denn er ist nicht nur Grossvater und Glied der Achtheit bzw. diese selbst; er ist, insofern er Sonnengott ist, auch 'Kind' und 'Same' der acht Urgötter', die ja die Sonne hervorbrachten,” H. Bonnet (2000), p.35.

38) On the appropriateness of the image of the Ouroboros for a self-thinking entity, see E.C. Clarke, J. Dillon, and J.P. Hershbell (2003) 309n407. 
and perhaps Iamblichus was familiar with these passages as well as whatever, if any, mention had been made of Kmeph in the Hermetic work he used as his source. At De Iside et Osiride 21, Plutarch identifies Kneph as

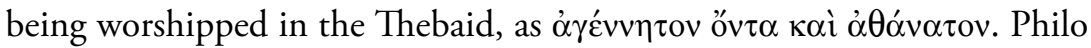
of Byblos is reported by Eusebius at Prep. Ev. III, 11, 45, describing a ser-

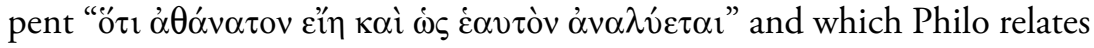
that the Phoenicians called Agathos Daimon and the Egyptians, Kneph. ${ }^{39}$ Kmeph also significantly enough in the context of theurgy appears several times in the Greek magical papyri; two occurrences are especially noteworthy, PGM III 142, where Kmeph is associated with Helios, and PGM IV 1705, with Agathos Daimon, a deity invoked frequently in the papyri. ${ }^{40}$ Another attestation likely appearing before the composition of de Mysteriis is in fact found in one of the fragments of Porphyry's De cultu simulacrorum, though it may have originated from Chaeremon. ${ }^{41}$ Porphyry refers to Kneph directly as the Demiurge and describes him as having a human form, holding a scepter and an ankh, with a feather on his head, all typically depicted visual aspects of Amun, characteristics which Porphyry then glosses with various one word explanations, including the reason for the

39) K. Sethe (1929), p.27, draws more parallels between Philo's description of Kneph and Agathos Daimon with the Egyptian "Lebenszeitschlange" related to Kematef and Amun. 40) Cf. H.J. Thissen (1996) 159-169, for a discussion of both including useful proposals for the Egyptian language equivalents standing behind the otherwise unintelligible magic words in the texts.

41) Smith 360F, also included by P.W. van der Horst (1987) 28-33 as Fragment 17D, one of his dubious fragments, though in his notes ad loc van der Horst 64-65 gives the arguments pro and rates it as probably an authentic fragment of Chaeremon. Whoever the original source is may, according to D. Mendel (2003) 181-191, have actually been intimately familiar with the Khonsu cosmogony at Karnak. She argues rather persuasively that the many parallels of details between Porphyry's textual description of Kmeph and the visual aspects depicted at Karnak are too numerous to represent a chance coincidence, that either Chaeremon himself or his source must have viewed and recorded the temple representation of Amun-Re on the west wall of the chapel of the barque or some preliminary modeling recorded on papyrus preceding the execution of the actual visual decorations. In any event, there is of course no evidence that Iamblichus knew directly or even indirectly the Khonsu cosmogony, but if Mendel is correct, she can at least offer not unreasonable evidence that valid knowledge of late Egyptian theology was passing to apparently interested parties like Porphyry via likely well informed intermediaries of Egyptian provenance, such as Chaeremon. How much, however, these sources distorted or by reinterpretation shaped the transmission is also with the present state of evidence not easy to determine. 


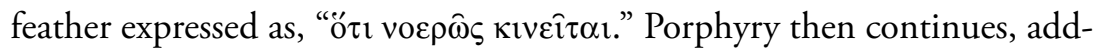
ing the information that Ptah, whom the Greeks take to be Hephaistos, was born as an egg from the mouth of Kneph and that the egg is interpreted as the cosmos. Iamblichus later in de Myst.VIII.3 also points out that the Greeks associate Ptah with Hephaistos, but in Iamblichus' view with the qualification that they do so "concentrating only on his technical ability." He makes this distinction most likely because he is emphasizing in this passage rather the Demiurgic nature of Ptah, but perhaps he is offering yet another retort to Porphyry's mistaken strictly materialist view of Egyptian religion, and it seems appropriate to ask in this context if the fact that Chaeremon was a Stoic and was apparently a main source for Porphyry's knowledge of Egypt has influenced Porphyry's restrictive concept of Egyptian religion. ${ }^{42}$ The image of the cosmic egg brought forth by Amun appears also in a purely Egyptian context as a part of the theology of the Ogdoad already discussed in connection with Kematef and is related to the bringing forth of light and the sun from Nun. ${ }^{43}$ Again it is no less difficult to determine exactly the extent of the familiarity that Porphyry had with Egyptian religion than to know how well versed in the subject Iamblichus was, and it is easy to view Chaeremon as the conduit to Porphyry for all this information, but the limited evidence also does not really allow even that minimalist conclusion. It is not a given as well that Iamblichus would have been familiar even with these earlier Greek references to Kmeph, though that possibility is at least more likely in the case of Porphyry. At any rate, Iamblichus clearly places Kmeph at the level of Nous, above the material world, as shown in his characterization of Kmeph as an "intellect thinking himself", and it is very tempting to view Iamblichus here as directly picking up somehow on Porphyry's own use of Kneph in his De cultu simulacrorum.

42) Chaeremon Fragment 5, P.W. van der Horst (1987) 14, which is also Epistula ad Anebonem II 12-13 Sodano, supplies apt examples of Chaeremon's conception and is very similar to Iamblichus' own representation of Chaeremon in de Myst. VIII.4.

43) For the cosmic egg and Ptah, see K. Sethe (1929) 62-63, H. Bonnet (2000) 162-65, and D. Mendel (2003) 44-47. Such an egg of course also occupies an important high position in the Orphic theology that was so significant for the later Neoplatonists, appearing as a product of Chronos, from which arose in turn Protogonos or Phanes. M.L. West sees parallels among several Oriental time gods, including the Egyptian Ra, and the Orphic Chronos, and between the fundamental figures of the cosmic egg in the Egyptian and Orphic systems; see West (1983) 104-106, 187-189. 


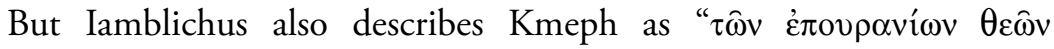

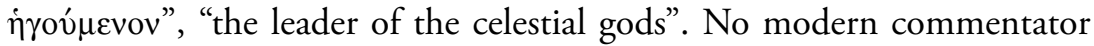
has explicated this characterization to clarify its meaning in Neoplatonic terms. Because of the noeric nature given him by lamblichus Kmeph must dwell above the encosmic realm and yet at the same time is called the "leader of the celestial gods"; since in the latter regard Kmeph would appear to be considered celestial, it would seem likely that he must inhabit that same lower encosmic realm rather than the higher noeric realm. This apparent contradiction troubled Walter Scott enough that in the presentation of this passage as a supplement in his edition of the Hermetica he found it required him to edit out the entire phrase from his text as an interpolation. ${ }^{44}$ There is however a solution that may be offered for this problem, and it lies in the divine, Neoplatonic identity of the "leader of the celestial gods": the god Helios should be advanced as the most likely candidate to be the Hellenic deity meant by Iamblichus to correspond to Kmeph in this role. ${ }^{45}$ The crucial characteristics supporting this identification are to be found in the use of "i $\gamma$ rov $\mu \varepsilon v o v$ " to describe this entity, Iamblichus' conception of Kmeph as noeric and as a god "thinking himself", and the fact that Kmeph/Kematef in Egyptian religion was associated with the sun via his relationship to Amun-Re. Already in Hellenistic astrology the sun as the supreme celestial body was typically referred to by means of some form of the term "i $\gamma \varepsilon \mu \omega v^{\prime}$ "; one good example is afforded

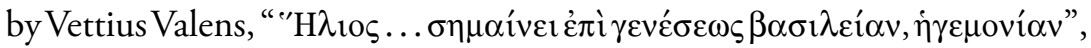

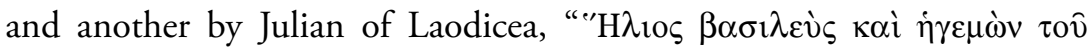
$\sigma 0 ́ \mu \pi \alpha v \tau о \varsigma$ кó $\sigma \mu о v . "{ }^{46}$ Also the concept of an intelligent or noeric sun can

\footnotetext{
44) W. Scott (1985) 59-60.

45) One commentator, Thomas Taylor, in Iamblichus transl. Thomas Taylor (1999) 192, actually does attempt to identify Kmeph as Saturn, or Kronos, on the basis of his status in Neoplatonic theology high in the intellectual realm. It will be shown below which god in that hierarchy is a stronger candidate.

46) Quoted in F. Cumont (1911) 452n2 and 453n1. Several other examples of these usages are provided by Cumont, including one from Theon of Smyrna attributing this notion to the Pythagoreans. Cumont's study is still a very useful survey of this subject, and contains many citations of astrological and other rather esoteric authors conveniently assembled together. Cumont's position is that the kingly notion of the sun originated in Mesopotamia, among the Chaldeans, and was transmitted into the West via Syria, the homeland, of course, of Iamblichus.
} 
be found in these earlier writers, though it may have been influenced as well by the Stoic concept of vozpòv $\pi \hat{v} \rho$. This idea likely developed rather naturally as an extension of the commanding power of the sun as it regulates the motions of the stars and planets from its position in the middle of the celestial spheres, eventually coming to be seen as necessarily requiring some supreme intelligence in order to govern such highly rational and farflung movements of celestial bodies. ${ }^{47}$ But more directly pertinent and contemporary evidence for this identification is to be found in Julian's Hymn to King Helios, in which a Neoplatonic solar theology is laid out in fairly detailed terms. Julian's presentation however has been accepted by scholars to reflect for the most part the teachings of Iamblichus himself as handed down to Julian through his philosophical mentors, Aedesius and Maximus, both devout followers of Iamblichus. ${ }^{48}$ In the Hymn Julian presents in fact three forms of Helios: "From Iamblichus is derived Julian's

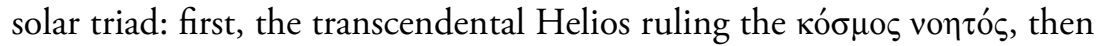
Helios as the supreme centre of the realm of $\theta$ coì voepoí (the Iamblichean realm unknown to Plotinus), and thirdly the visible sun governing the world of sense perception." ${ }^{39}$ Julian makes it very clear in the Hymn that Helios rules the noeric gods by the direct authority of the Good and is also,

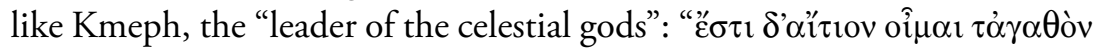

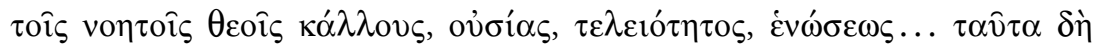

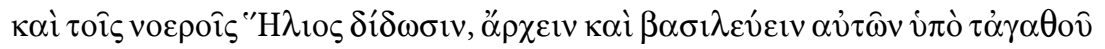

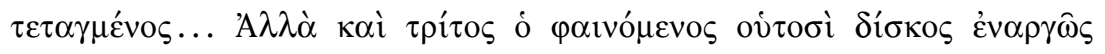

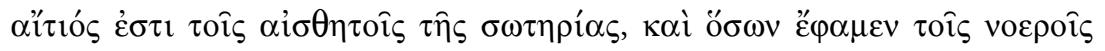

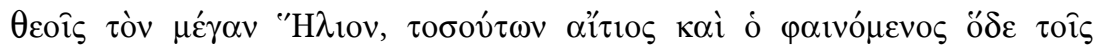

47) This development is documented by F. Cumont (1911) 457-62, including the possible Stoic influence of the notion of intelligent fire transferred to noeric light, hence to the light of a noeric sun. Cumont (453) also cites fragments of the Chaldaean Oracles on the noeric sun as well as a number of later Neoplatonists, including interestingly enough Porphyry from his Isagoge to Ptolemy's Tetrabiblos in which he describes Helios as "кро́ $\tau 1 \sigma \tau о \varsigma \tau 1 \varsigma$

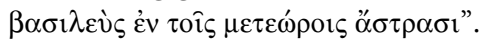

48) On Julian and his Iamblichean mentors, see R.E. Witt (1975) 47-48, and R. Smith (1995) 29-30.

49) R.E. Witt (1975) 52. For the concept of the noeric sun as it appears prominently in the Chaldaean Oracles, with which Iamblichus clearly was intimately familiar, given his massive lost commentary on them, see H. Lewy (1978) 151, and, working back mostly but not exclusively from Proclus, W. Fauth (1995) 136ff, and for his discussion of Julian's Hymn, 147-164. 
pavepoî.." ${ }^{50}$ But since Kmeph is also noeric, "the intellect thinking himself", it is most likely that Julian's—and Iamblichus'-second Helios, the "supreme centre of the realm of $\theta$ coi vorpoí" is actually the specific Neoplatonic deity intended by Iamblichus to be represented in Kmeph. There is more evidence of the similarity of roles for Kmeph and Helios to found in the Hymn; the first sun is identified by Julian with the Good or the One at $O r$ IV $132 \mathrm{C}-133 \mathrm{C}$ and John Finamore argues that this sun, according to Iamblichus' melding of the Chaldaean system and his interpretation of

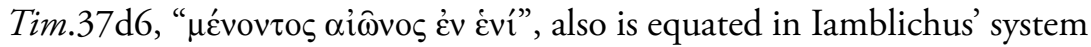
to Aion, which is a "horizontal extension" of the One Existent. ${ }^{51}$ Finamore continues: "Thus, Helios' role as the middlemost entity of the middlemost realm is to link the gods of the noetic realm with the visible gods. He is, therefore, to be placed at the summit of the noeric realm just as Aion was placed at the summit of the noetic." 52 But Kmeph is ranked by Iamblichus below Heikton, who was shown above to occupy the Neoplatonic position of indeed that same One Existent, so Kmeph's position in the hierarchy is analogous to that of the noeric sun also below Aion. There is direct evidence of association of Helios and Kmeph offered by another, though later, Neoplatonist. At de Prin. 125 (Westerink and Combès III.167.1-24), Damascius reports some of the researches on Egyptian religion by Heraiscus and Asclepiades, the uncle and father of Horapollo the philosopher in whose school Damascius had studied in Alexandria: Asclepiades claims that a first Kmeph is born from the two primary elements Sand and Water, which then himself engenders a second and third Kmeph, and these three

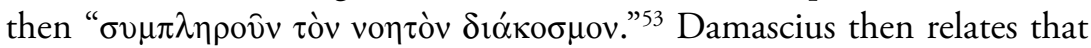

50) Hymn, Or. IV 133B-C. J. Finamore (1985) 136-140, explicates Julian's solar theology thoroughly, relating it to Iamblichus' thought and as well as theology of the Chaldaean Oracles. See also now J. Dillon (1999) 103-15.

51) J. Finamore (1985) 136. For Aion in Iamblichus' philosophy, see J. Dillon (1973) 35, and J. Dillon (1987) 887.

52) J. Finamore (1985) 136. D. Ulansey (1994) 257-264 makes the intriguing argument that Mithras himself can also be identified with the noeric sun, and includes a short survey of the development of the concept, starting with Plato's Phaedrus and an interesting passage in Philo.

53) Aside from this passage in de Prin., other details about Heraiscus and Asclepiades are preserved in Damascius' Philosophical History, especially Fragments 72A-E Athanassiadi. See also Damascius ed. and transl. P. Athanassiadi (1999) 20-21, and Damascius ed. and transl. G. Westerink and J. Combès (1991) 239-240. Among other accomplishments, 
Heraiscus identifies Kmeph, "named after his grandfather and father," with

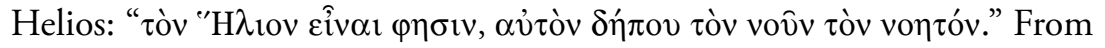
the viewpoint of Egyptian religion, what apparently is reflected here is the association of Kematef with Amun-Re and the Ogdoad, the latter of which arose from the primordial mud most likely referred to in the Sand of the text, with Water representing most likely Nun. ${ }^{54}$ Since Heraiscus and Asclepiades do postdate Iamblichus, this passage cannot offer evidence of Kmeph as Helios in the third or fourth century, and furthermore it offers only evidence that Kmeph was associated with Helios and not necessarily the noeric sun, perhaps merely occurring in the context of some interest in the Egyptian sun god Amun-Re and the theology of the Ogdoad originating in Heliopolis. But nevertheless it is still an identification reported in the Hellenic tradition in Greek, by a major Neoplatonist, and as such worth at least citing, and especially since Damascius refers to Kmeph as

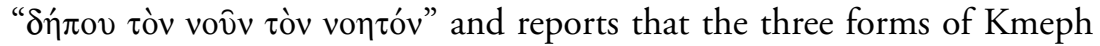
"fill the noetic realm", thus, like Iamblichus, making Kmeph a figure of the noetic-noeric realm.

Finamore additionally argues the importance of the fact that Julian goes on to equate this second Helios with Zeus as Demiurge, finding more evidence of this synthesis in Macrobius Sat. I.23, but he attributes the notion also originally to Iamblichus, again working back from Julian: at

Asclepiades was claimed by Damascius to be an expert on Egyptian theology and had also written a treatise that was an "agreement of all theologies" (Fragment 72E); it is probably not unreasonable to speculate that the work was Neoplatonic in nature, given Damascius' praise of it. It is also interesting to note that Damascius makes no explicit reference to de Myst. VIII here, though it is not possible to judge the true significance of that omission. It is however reasonable to ask if Asclepiades dealt with de Mysteriis or any other work of Iamblichus in his lost treatise on theology, and to wonder about the true extent and nature of his understanding of Egyptian religion, and how Neoplatonic or not his conception of it might have been.

54) "Auch die Aufspaltung in drei Formen des Kmeph lassen sich allenfalls auf die erwähnten drei Generationen Amuns beziehen: Kematef und Irta... die dritte Form, Kmeph als Sonne, wäre dann als Anspielung auf Amun-Re verstehen," H.J. Thissen (1996) 158. Thissen also makes it clear that it is Kmeph/Kematef who is referred to here in the Greek K $\mu \eta \varphi ı$, and not Kamephis/Kamutef. He observes finally, appropriately enough perhaps for this present analysis, "Es wäre eine reizvolle, aber vermutlich dornenvolle Aufgabe, den Wegen nachzuspüren, auf denen die ägyptischen Vorstellungen zu den Neuplatonikern gelangten." 


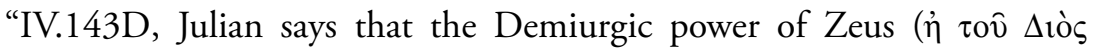
$\delta \eta \mu \iota v \rho \gamma ı \kappa \eta ~ \delta v ́ v \alpha \mu \iota)$ coincides with Helios." ${ }^{\prime 5}$ Later Julian claims that Helios and Zeus have equal and identical dominion over "the separate creation which is prior to substances, in the region, that is to say, of the absolute causes which, separated from visible creation, existed prior to it." ${ }^{56}$ Proclus in the Platonic Theology VI.12,25ff, referring to the Timaeus, speaks of the double Demiurgy of the Sun, one physical and coordinated with the other physical heavenly bodies, and the second, which is " $\tau \grave{\eta} v \delta \grave{\varepsilon}$

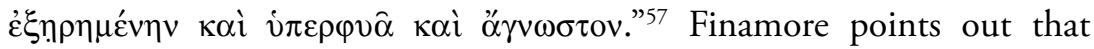
Macrobius in the passage referred to above imputes to Plato himself the desire that "this Zeus be identified with Helios" after quoting Phaedrus

55) J. Finamore (1985) 137. Cf. J. Dillon (1973) 418-19: "Julian, in Or.5 (172D), refers to

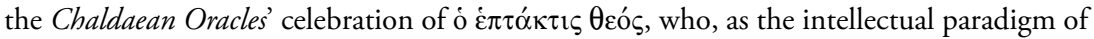
the celestial Helios, will be in fact the Demiurge, the Helios of Julian's Oration Four." The Neoplatonic influence on Macrobius may well be Porphyry and not Iamblichus, though the concepts expressed are nonetheless similar, and there is no controversy in the case of Julian. P. Courcelle (1969) 28-31 surveys the earlier scholarship on this issue and argues strongly for Porphyry based in part of the evidence of Servius' reference in his in Buc. to a work by Porphyry on the Sun, called Sol, though he also points out that Macrobius and Julian in their works "on the sun reveal a common doctrine, though not a textual dependence" (29). S. Gersh (1986) 558-562 follows Courcelle's view of Porphyrian influence on Macrobius and discusses what he sees as Porphyry's own view of a physical and a noeric sun, likely set forth in the lost work Sol, in turn influenced by Chaldaean solar theology. Iamblichus thus may again be appealing to Porphyry's own thought, admittedly indirectly, when he associates Kmeph with the noeric sun. It should be recalled that in Fragment 17D of Chaeremon, Porphyry refers to Kneph as the Demiurge, and in Fragment 5 of Chaeremon, he comments on those Egyptians who think the sun is the Demiurge.

56) Or. IV 144B. Julian transl. W.C. Wright (1980) 393. J. Dillon (1999) 110 also points out that Julian has made this link with Zeus, who was already seen in this Demiurgic role by Plotinus.

57) Cf. Proclus ed. and transl. by H.D. Saffrey and L.G. Westerink (1997) 156 n5 ad loc. for reference to a similar description by Proclus at in Tim. III, p.53.6-13, where he again terms the Demiurgy as double, with one physical and the other "invisible", "unique", "simple", "hypercosmic", and "noeric". Proclus refers again to a higher, hypercosmic sun at in Parm. VI. 1044-45, where he also relates it and its counterpart in the physical world, the visible sun, to the doctrine of henads. For a analysis of how Proclus' Hymn to Helios, where the god

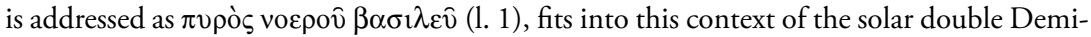
urgy and its relation to the above cited passage in Platonic Theology VI, see Proclus ed. and transl. R.M. van den Berg (2001) 152-155. Hermias in his Commentary on the Phaedrus at 82.12 also alludes, albeit rather cryptically, to the double Demiurgy. 


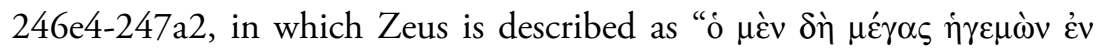
ov่pavọ." ${ }^{p 8}$ Hermias at 136.17-30 in his Commentary on the Phaedrus criticizes Iamblichus by name for associating the Zeus of this same passage in the dialogue with the "one Demiurge of the cosmos," "transcendental Demiurge" and "Demiurgic Monad", though he grants that Iamblichus is right to associate Zeus with this higher Demiurge, just not the Zeus of the Phaedrus, whom he sees rather as the Zeus of the triad of Zeus, Pluto, and Poseidon at what is the hypercosmic level of the later theology of Syrianus and Proclus (Hermias' Commentary is most likely drawn from his notes taken from lectures of his master, Syrianus)..$^{9}$ Iamblichus appears to have developed a hierarchy for the noetic-noeric realm as complex as that known from the later Athenian Platonists, such as Proclus, in that he establishes levels of intelligible gods, intelligible-intellectual, and a hebdomad of intellectual gods; the evidence for this view is limited to inferences drawn from Proclus' discussion of Iamblichus' conception of the Demiurge at I.308.18ff of his Commentary on the Timaeus, where Proclus also refers to a separate essay by Iamblichus entitled "On the Speech of Zeus in the Timaeus" ${ }^{60}$ It is in the first triad of "Fathers" among the intellectual gods that Iamblichus placed the highest Demiurge to whom Hermias refers in his Commentary, who is identified with Zeus, again whom, according to Hermias, Iamblichus associated also with the Zeus as $\mu \varepsilon^{\prime} \gamma \alpha \varsigma$ i $\gamma \varepsilon \mu \omega \dot{v}$ of the Phaedrus. But it is noteworthy that Iamblichus uses exactly the same term for leadership in his gloss of Kmeph, as "irov́ $\mu \varepsilon v o v$ " of the celestial gods, and in fact earlier

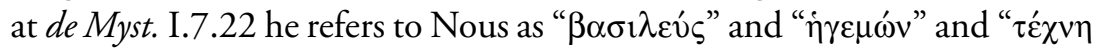

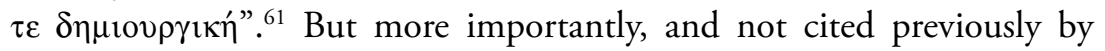
any commentator, is the fact that Proclus characterizes Zeus, exactly as

\footnotetext{
58) J. Finamore (1985) 137.

59) For a detailed discussion of this passage in Hermias, see Proclus ed. and transl. by H.D. Saffrey and L.G. Westerink (1997) xx-xxviii. For his criticism of Iamblichus and the distinction of the two Zeus', see also the brief comments of I. Hadot (2004) 58-59, and the more detailed discussion of D. O'Meara (1989) 138-139.

${ }^{60)}$ For a thorough examination of this treatise and how it relates to Iamblichus' thought, see J. Dillon (1973), Appendix C, 417-419, J. Dillon (1987) 889, and J. Opsomer (2005) 74-78; cf. W. Deuse (1977) 273-274.

61) E.C. Clarke, J. Dillon, and J.P. Hershbell (2003) 29n44, points out that Iamblichus is likely alluding here via these epithets to two passages in Plato, Phaedrus 246e4, cited above, and Philebus 30d1-2, so that Zeus in both cases is identified with the hypostasis of Nous.
} 
Iamblichus does Kmeph, as an "intellect thinking himself" at Platonic The-

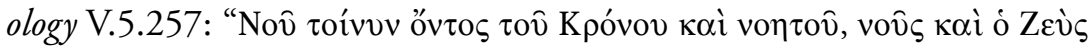

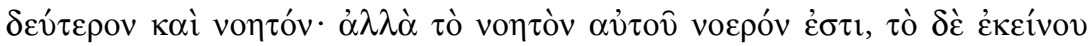

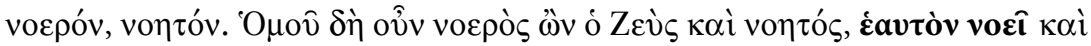

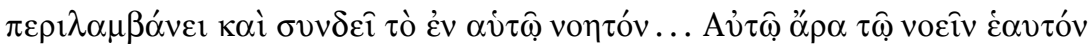

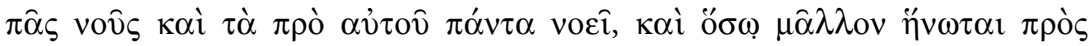

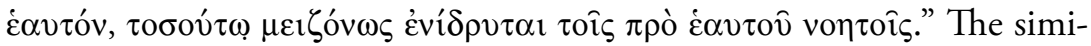
larity of the two passages is very striking, and since the shared characterization itself is rather unusual, the fact that a god thinking himself appears in both passages strengthens the possibility that the same god is being referred to in both. Proclus is describing Zeus here at the same level as Iamblichus' Demiurgic Zeus, occupying the position of Demiurge in the triad of intellectual Fathers; in fact the subject matter of Book V of the Platonic Theology encompasses all the intellectual gods. In Proposition 167 of his Elements of Theology Proclus also discusses this concept of intellection, where the highest Nous, Kronos in the passage from the Platonic Theology Book V above, only knows itself, and its intellect and object are numerically one and identical, and the next, subsequent intellect, Zeus as in the same passage above, knows itself and its superior, "so that its object is in part itself but in part its source." 62 E.R. Dodds in commenting on this Proposition describes the self-thinking intellect as the first of a "series of lower vó $s$ which are not identical with their objects but know them $\kappa \alpha \tau \grave{\alpha} \mu \varepsilon^{\prime} \theta \varepsilon \xi_{1 v}$, as

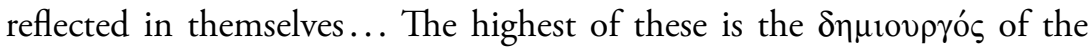
Timaeus"; Dodds goes on to attribute the origin of this concept to Syrianus, but if the identification of Kmeph and this Demiurgic Paternal Zeus as an intellectual god is correct, then perhaps it really was initiated earlier by Iamblichus. ${ }^{63}$ The passage in Proclus' Timaeus Commentary at I.308 cited above is however problematic, for at first he states that Iamblichus defines the Demiurge as the god who "gathers into one and holds within himself... Real Existence and the beginning of created things and the

62) Translation of Proclus transl. E.R. Dodds (1963) 145. For his commentary on this passage, see 285-286.

63) Proclus transl. E.R. Dodds (1963) 286, where he also comments on the difficulties of understanding how the Demiurge relates to the Paradigm and the various Neoplatonist solutions for them. Both Dodds, 289, and E.C. Clarke, J. Dillon, and J.P. Hershbell (2003) $31 \ln 408$, point out that the notion of the self-thinking god ultimately goes back to Aristotle's Unmoved Mover. 
intelligible paradigms of the cosmos, which we term the intelligible cosmos, and such causes as we declare to pre-exist all things in Nature," and Proclus then goes on to cite Iamblichus' other formulation in the essay on the "Speech of Zeus", after criticizing him for this first position, which Proclus interprets to mean that he must have intended for the whole of Nous, the entire noetic-noeric realm, to be taken as the Demiurge. ${ }^{64}$ But what if rather Iamblichus is referring to an intellectual act when he speaks

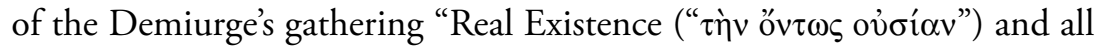
the other noetic elements referred to in the quotation? Is this not possibly an act just like that defined in Proclus' Proposition 167 as one performed by those "lower vó $\varsigma$ " when they internalize in thought all the noetic elements higher than themselves, chief of which "lower vó $\varepsilon \varsigma "$ is, as Dodds points out, the Demiurge of the Timaeus? Proclus himself at Platonic Theology V.17.11-14 makes almost the same observation about the Demiurge:

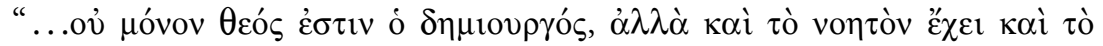

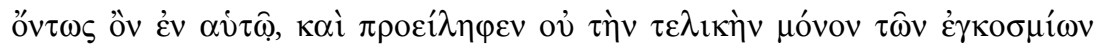

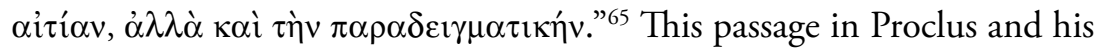
quotation of Iamblichus on the Demiurge from in Tim. I.308 are very similar in the language used in each instance, so much so that Proclus could almost be paraphrasing Iamblichus. Is this concept of noeric selfthought and gathering-in possibly the best interpretation of Iamblichus' definition of the Demiurge, which maintains on the one hand the exact sense of the text, and also allows it to be quite consistent with the view set forth in his essay on the "Speech of Zeus" without however forcing Proclus' problematic conclusion that Iamblichus' Demiurge must equate literally with the entire realm of Nous? ${ }^{36}$

\footnotetext{
64) Translation of Proclus by J. Dillon (1973) 137.

65) Cf. L. Siorvanes (1996) 151-152, where he translates this passage and gives a good explication of the three Fathers from Proclus' philosophy. J. Opsomer (2005) 77 discusses the internalization into the Demiurge of otherwise external existing realities, and translates this passage also from Proclus in Tim. I.307.26-31 which offers more proof, in a rather allusive way, of Zeus' role: "If what <lamblichus> means by these words is that the demiurge, too, everything - 'real being' as well as 'the intelligible world' - exists in a demiurgic manner, he agrees with himself and with Orpheus who says that 'all these lie in the body of the great Zeus."”

66) The concept of reflective intellective deities is also to be found in another later Neoplatonist, Olympiodorus. In the introduction to the Gorgias Commentary, Olympiodorus transl. Robin Jackson, Kimon Lycos, and Harold Tarrant (1998) 23-28, Harold Tarrant
} 
If this inference that Kmeph is to be equated with Helios as the noeric sun and Paternal Demiurge is a valid representation of Iamblichus' thought, then perhaps there is now evidence here for a specific link to other extant Hermetic texts, though none has ever been detected previously which could be directly associated with this or any other portion of de Mysteriis, in spite of the fact the Iamblichus is claiming to be presenting Hermetic doctrine. ${ }^{67}$ In chapter VIII.5 he points out that the "prophet" Bitys has handed down to Ammon teachings concerning a transcendent god who acts as Demiurgic; treatise XVI of the Corpus Hermeticum also is addressed

addresses Olympiodorus' contention from the Proem (0.4) that the skopos of the dialogue is wrongly taken by some to be the Demiurge, as well as a similar criticism of an unnamed commentator made in the Anonymous Prolegomena to the Philosophy of Plato that the skopos of the Gorgias was "the intellect which sees itself." This latter intellect however is explicitly designated by Olympiodorus in his Commentary on the Phaedo (1.5) as Kronos, portrayed there literally as a god who sees himself. Olympiodorus later in the Commentary on theGorgias (47.3) represents Kronos in much the same descriptive language, including the curious notion that the god produces and devours his own children because of this reflective nature, though omitting there specifically to term Kronos as a self-seeing god. Westerink and Trouillard in Anonymous edited and translated by L.G. Westerink and J. Trouillard (1990), 72n194, commenting on the criticism of the skopos in the Anonymous Prolegomena, attribute this concept of reflection rather to Amelius and make no reference to the overt identification with Kronos by Olympiodorus in his Commentary on the Phaedo. They do however cite his Commentary on the Gorgias for Zeus as the self-seeing god, which they also prefer to see as originating with Amelius, but as illustration give a Lecture reference in the Commentary of 3.14-17 that does not appear to correspond to any part of the work within the usual numbering schema, although as noted above Lecture 47.3 describes Kronos as an intellective god with a distinctly reflective nature just as in the passage in the Commentary on the Phaedo; nowhere in the Commentary on the Gorgias is Zeus depicted in such terms, and Amelius is not cited or referred to anywhere in the Commentary on the Gorgias. Cf. Olympiodorus (1998) 24 for Tarrant's significant criticism of their view on Amelius. This representation of Kronos as a god seeing himself moreover offers further proof that Kmeph as a god thinking himself is more appropriately associated with Zeus, and not, as Thomas Taylor had done, with Kronos. It is not clear exactly to whom Olympiodorus and the Anonymous Prologomena refer in their criticism for the incorrect determination of the skopos of the Gorgias; Iamblichus would natually come to mind, but the lack of any fragments of any work by him on that dialogue prohibits identifying him with certainty as the target of their remarks: Olympiodorus (1998) 23-24.

67) For some examples of generally similar language regarding the highest god found in various Hermetic texts, see H.D. Saffrey (1992) 161-162, though he first asserts that there is nothing specifically like the hierarchies expressed in de Myst. VIII to be found in any of the extant Hermetica. 
to Ammon. ${ }^{68}$ But C.H. XVI contains perhaps an even more significant specific link to de Myst. VIII in its depiction of in fact that same noeric sun as found in Julian and, as proposed here, Iamblichus' Egyptian Kmeph. In chapter 5 and 6 of the treatise the sun is said to transmit essence to the earth from heaven and as $\delta \eta \mu$ tovpró $\varsigma$ bind the two together, and it consists

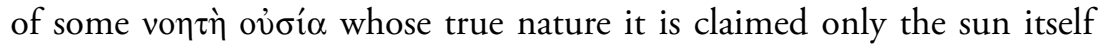
"knows." Later in chapter 17 the intelligible cosmos is described as depending from god and the sensible cosmos from the intelligible, but also that the sun is provided by the primary god through both the intelligible and sensible with a channeling of the Good, that is through the sun's role as Demiurge. This characterization of the sun as noeric and Demiurgic allows this passage to find a later echo in Julian's Hymn to the Sun, which as has been seen reflects Iamblichus' own doctrines, and since C.H.XVI is quoted in the Divine Institutes of Lactantius, it appears chronologically possible that this particular Hermetic text was available to Iamblichus during his lifetime. ${ }^{69}$ While the philosophical concepts regarding the sun expressed in this Hermetic text are much simpler than what Iamblichus presents in de Myst.VIII, it is possible, regardless of whether Iamblichus was in any way directly influenced by this specific passage in the Hermetica in his conception of Kmeph as noeric sun and Demiurge, that this is a typical Hermetic formulation concerning solar theology that Iamblichus might have found in whichever of the Hermetica was his source. ${ }^{70}$

68) G. Fowden (1993) 140-41, sees de Myst. VIII.5-VIII.6 as showing in general, again not specifically, the closest affinity with "theurgical" Hermetica; cf. B. P. Copenhaver (1992) 201, for his interpretation of Fowden's view in the context of C.H. XVI.

69) See G. Fowden (1993) 206 on Lactantius' use of C.H. XVI and other Hermetic texts.

70) Elsewhere in the Hermetica, the visible sun is addressed also in Asclepius 29, where it is referred to as the "second god". Perhaps more noteworthy, though not necessarily to be linked directly with Kmeph as either the Paternal Demiurgic Zeus or Helios, are the ousiarchs expounded in Asclepius 19, in which Jupiter is called the ousiarch of heaven and Light the ousiarch of Sol, where Jupiter and Light are both intelligible gods giving rise to the physical, so that Light is the intelligible counterpart to Sol, mentioned later as the visible sun and "second god" in chapter 29. Festugière (1967b) 127-130, links the concepts expressed here via the term "ousiarch" to a passage later in de Myst. VIII at VIII.8.271.5-8,

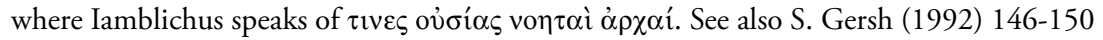
for a thorough discussion, incorporating Festugière's work, of the theology expressed in this Hermetic treatise, whose text in these chapters is not an easy one to interpret. That there are affinities between the Asclepius and Iamblichus seems clear, again though only in a rather general way, and though Jupiter and Light and Sol are ranked in the Asclepius, there is no 
As was referred to above in the discussion of Julian's Hymn, this notion of a noeric sun most likely first appeared in a Platonic context in the Chaldaean Oracles, where it also was associated with a sort of non-physical time. Hans Lewy equated Aion with this "transmundane sun", as he termed it, but later scholars have discounted this identification, for among other reasons the fact that the name Aion does not itself actually appear in the quoted texts of any of the hexameter verses of the Oracles, and because Lewy based much of his judgment on evidence regarding Aion found in the Tübingen Theosophy and not the Oracles themselves. ${ }^{71}$ E.R. Dodds preferred to see the god in question here rather as Chronos, and in Oracle 185 preserved by Proclus in his Timaeus Commentary III.36, 20-22, the noeric

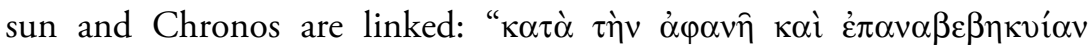

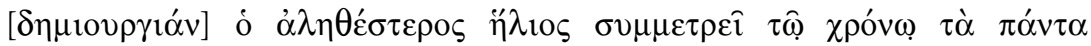

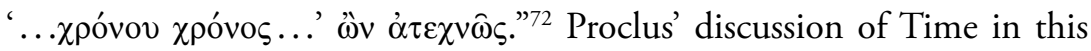
section of his Commentary is thought to represent mostly the views of Iamblichus. ${ }^{73}$ The One Existent, as represented by Aion, or Eternity, serves as the highest instantiation of time, a measure of the noetic realm in the system of Iamblichus. ${ }^{74}$ But there appears also to be an another Neoplatonic instantiation of time at the noeric level, below Aion but still not a physical type of time; Fragment 63 of his Commentary on the Timaeus, drawn from Simplicius, distinguishes this ideal, non-physical time from

real evidence that the hierarchies given in both de Myst. VIII as regards Kmeph and the Hermetic treatise are actually the same, or that Iamblichus somehow borrowed from the Asclepius directly. But again at least it seems likely that this is the sort of Hermetic text that Iamblichus must be referring to in de Myst. VIII and the milieu in which he is writing. Gersh 148-149 adduces the theology of the Chaldaean Oracles as the most likely common influence for both systems of thought.

71) Lewy (1978) 151; for the criticism of Lewy in the same volume, E.R. Dodds, (1978) 696, and R. Majercik (1989) 14-16.

72) Cited in Lewy (1978) 152, though he is attributing this to Aion. G. Shaw (1995) also refers to this passage and Proclus in Parm. 1044-45, when discussing the importance of Helios in theurgy, calling Helios "the hidden sun".

73) According to Proclus ed. and tranls. E.R. Dodds (1963) 228, commenting on Proposition 53, which is concerned with Eternity, or Aion, and Time, or Chronos, and J. Dillon (1973) 345-46, commenting on Iamblichus Fragment 63 in Tim., also dealing with the same subjects, and S. Sambursky and S. Pines (1971) 17.

74) J. Dillon (1973) 35 for the identification of Aion with the One Existent, and pp.346-47 on Fragment 63. 
the normal physical time that philosophers would usually study in their enquiries about the physical universe. Sambursky has detected in this passage in Simplicius Phys. 792,20-795,3 (including but also extending beyond Dillon's Fragment 63 of Iamblichus in Tim.) strong evidence for this noeric time, though admittedly nowhere in either Simplicius' text nor his direct citations of Iamblichus does the exact term noeros appear. ${ }^{75}$ Again, in that section of his Timaeus Commentary where Proclus is thought to be representing the views of Iamblichus, he argues that $\chi \rho o ́ v o s$ has an

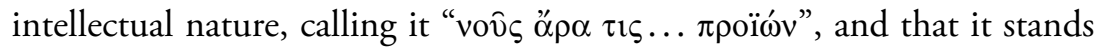
between Aion and the level of the Soul and leads all things in a circle. ${ }^{76}$ Later at III 53,6ff Proclus links this intellectual time inextricably with the higher noeric and hypercosmic element of the double Demiurgy, which again is associated with the noeric sun and the Paternal Zeus and contrasts the unified nature of the intellectual time with the divided nature of the lower physical time that characterizes time as humans experience it in a

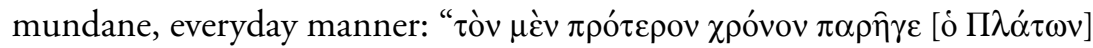

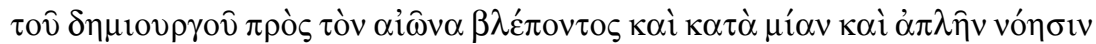

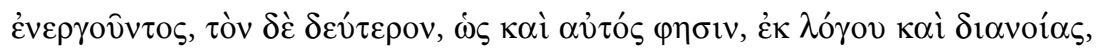

75) J. Dillon (1973) 346-47 does not go as far as Sambursky to term this "noeric" time, rather refers to an "Absolute" time, which however is clearly not Aion nor physical time. For Sambursky's discussion, see S. Sambursky and S. Pines (1971) 11 and his notes to the Simplicius passage, 107. The most telling evidence, though the whole passage is compelling, is at 793, (40, line 24ff), which Sambursky translates "In the eighth book [of Iamblichus' in Tim.] he follows Plato above all in propounding the connection between time [Chronos] and eternity [Aion]. Accordingly he discusses above all intellectual time which transcends the cosmos and encompasses and provides the measures of all movements that are in it. This time is different from the time which the physicists inquire into" (41), where however it should be noted that "noeros" does not actually appear in the Greek text, though

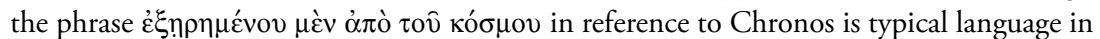
late Neoplatonism used to indicate the hypercosmic realm. In the cited notes Sambursky comments on the numerous terms used by Simplicius to designate this intellectual time. Again, "noeric" is not actually among those terms, but the passages included by Sambursky taken as a whole make it clear that it is a noeric entity being set forth here. Both Dillon and Sambursky are also in agreement that the time described by Simplicius provides rather a paradigmatic measure for physical time, that it does not itself measure anything physically, and that it is somehow above regular time, yet still not so exalted as Eternity.

76) Proclus in Tim. III,26, S. Sambursky and S. Pines (1971) 52 lines 10-11; cf. his notes on the circle ad loc p.109. At in Tim. III, 51, Proclus claims that Iamblichus says that time is halfway (“ $\mu \varepsilon \dot{\sigma \eta}$ ”) between Eternity and heaven. 


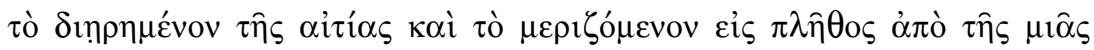

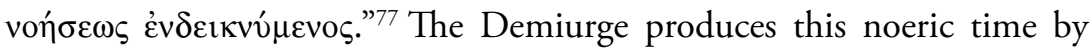
looking at Aion for its eternal paradigm and interestingly enough in a single intellection projects time. As mentioned above, Kmeph is the Egyptian god Kematef, literally "he who has completed his moment, his time", the serpent Ouroboros associated with creation. While there is of course no direct evidence that Iamblichus was aware of this time-related aspect of Kmeph, nor is there anything explicit in the text of de Myst. VIII that would indicate that he meant to link the noeric Kmeph, "the god who thinks himself" with any notion of noeric time, nevertheless the similarity is striking, if only coincidental. Aion as a deity may have arisen under the influence in Hellenistic times of the Persian time god Zervan Akarana, and appears several times in the Corpus Hermeticum and among the Greek magical papyri, including in direct association with Kmeph as the Ouroboros literally described as "biting its tail" on a phylactery in $P G M$ VII. $580 .^{78}$ Aion is also linked in the PGM with Helios and Agathos Demon, and Aion was often itself depicted as lion-headed and entwined with a serpent. ${ }^{79}$ In another papyrus, PGM IV 1596-1715, Helios is

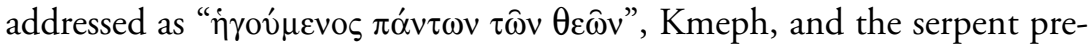
siding over the creation of Egypt. ${ }^{80}$ Again there is no specific evidence in de Mysteriis that Iamblichus understood Aion or Kmeph in this same constellation of imagery and religious functionality reflected in the magical papyri, but this confluence of Hellenistic and Egyptian beliefs was apparently a continuing presence in the late Roman spiritual milieu out of which the Hermetic texts arose.

77) Proclus, in Tim. III.57, S. Sambursky and S. Pines (1971) 54 lines 24-29.

78) On the relation to Zervan Akarana, see J. Dillon (1973) 35, where he also quotes the useful discussion of Proclus ed. and tranls. E.R. Dodds (1963) 228 on the Persian god in relation to Proposition 53 of the Elements of Theology. For a summary of the Persian Zervan, see Brisson (1995) 47-50; Brisson also places Chronos in the Orphic theology and gives a thorough comparative analysis of the Mithraic Aion sculpture from the Villa Albani and the Orphic Modena relief, both of which incorporate solar iconography and a main figure encircled by a serpent (45-46). On Aion in the Hermetica, see A.J. Festugière (1990) 152-175.

79) On Aion in the PGM, see A.J. Festugière (1990) 182-199 especially 197-198 on Helios.

80) Kmeph also occurs in PGM III.142, as noted above and by E.C. Clarke, J. Dillon, and J.P. Hershbell (2003) 309n407. For the interpretation of an alabaster bowl with winged 
If Kmeph can rightly be identified with Helios, it is also worthwhile to recall that Kmeph is an epithet for Amun-Re, the Egyptian god of the sun, acting in his Demiurgic capacity creating the world, and that Amun-Re was considered in late Egyptian theology the "noble Ba" of Kematef, hence a solar deity accessible to the sensory world. Just as the visible Helios reigns over the Demiurgy of the sensible universe, so does Amun-Re, with Kematef occupying an exalted position removed from the realm of the senses. Though there is of course no direct evidence that Iamblichus or for that matter Porphyry was aware of this concept of the Ba in Egyptian religion and this relationship between Kematef and Amun-Re, still the parallel between the Egyptian and Neoplatonic theologies is most striking and does at least raise the question that some such knowledge had been conveyed via some writer, perhaps like Chaeremon, to those interested outside of Egypt. As Helios Kmeph also would occupy a central position in the structure of theurgy delineated by Iamblichus in de Mysteriis. Gregory Shaw has elucidated in great detail the crucial role of Helios in the process of theurgy as described by Iamblichus: "the most distinctive cosmological feature in theurgy was the central position given the sun. For Iamblichus, Helios played the key role in the apotheosis of the soul: first awakening it through the senses and then leading it noetically to the eternal arithmoi." 1 Helios is the greatest theurgic $\sigma u v v \theta \eta \mu \alpha$, symbolizing to the One itself, and by its noeric fire it purifies the soul, which, once made pure, rides its lumi-

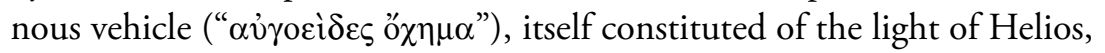
up to the sun itself where the soul is established as divine in consummation of the theurgic art. ${ }^{82}$ "In his Timaeus Commentary Iamblichus said the

serpent and what are apparently ritual celebrants carved on its interior and carrying an Orphic inscription on the exterior, see H. Leisegang (1955) 219ff where Leisegang adduces the evidence of these citations of Aion and Helios in the PGM, as well as the passage in Macrobius referred to above, among others, to offer a reading of this curious object similar in many respects to the solar theology being put forth here in explanation of Kmeph in Iamblichus.

${ }^{81)}$ G. Shaw (1995) 239.

82) For Helios as $\sigma u ́ v \theta \eta \mu \alpha$ see especially G. Shaw (1995) 225, and the entire chapter, "The Sunthema of the Sun" (216-228) is highly relevant, including his views on the ob $\chi \mu \alpha$ in this regard. The most detailed work on the latter is J. Finamore (1985). Shaw (228) emphasizes the crucial importance of this Helian theology to Iamblichus' theurgy: "The evidence suggests that the theurgic mysteries were solar mysteries, for the goal of all mantike and theurgic ritual as 'the ascent to the intelligible fire' $(D M 179,9-12)$ and theurgists, Iamblichus says, 'are true athletes of the Fire (DM 92, 13-14)'”. 
Paternal Demiurge (the hidden sun) contained the intelligible (i.e. hypercosmic) realm, just as Helios contained the encosmic powers of the zodiac." ${ }^{83} \mathrm{Kmeph}$ is then apparently Iamblichus' Egyptian counterpart to these Hellenic deities, the noeric Helios, or "hidden sun," as described by Julian, and Zeus the Paternal Demiurge in their Neoplatonic forms. Earlier in de Myst.VII.2 Iamblichus focuses the discussion on the Egyptian symbol of the lotus and the sun god riding in the solar barque, again utilizing Neoplatonic terms in his description, though he does not in that passage identify the solar divinity as Kmeph or any other named god. The god Harpocrates, though not actually referred to by name in the text, normally separated from the primordial mud by the lotus on which he sits, is depicted there by Iamblichus as an intellectual and Demiurgic god, totally transcending the material cosmos signified by the mud. The shining forth of the sun god Re is also symbolized in the lotus, and Iamblichus interprets the ride of the sun god in the barque also as the act of a transcendant Demiurge like Kmeph or the Paternal Demiurgic Zeus: "Just as the helmsman presides over the ship while taking charge of its rudder, so the sun is transcendentally in charge of the helm of the whole world. And as the helmsman controls everything from on high from the stern, giving out a minimal first impulse from himself, so in the same way, but more significantly, the god from on high gives out, indivisibly, from the first principles of nature, the primordial causes of movement." ${ }^{44}$ In the beginning of the next chapter the solar act of Demiurgy is delineated by distin-

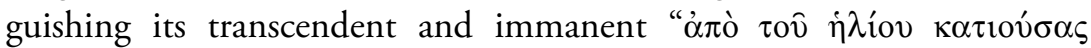
$\delta v v \alpha ́ \mu \varepsilon \varepsilon \varsigma$ " which bestow on the physical universe what Iamblichus refers

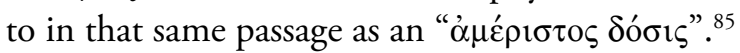

83) G. Shaw (1995) 177.

84) de Myst. VII.2.252.11-VII.3.253.11, translation of E.C. Clarke, J. Dillon, and J.P. Hershbell (2003) 295. Could the "causes of movement" here given out by the sun be reminiscent of the noeric movement attributed by Porphyry to Kneph in De cultu simulacrorum discussed above?

85) See G. Shaw (1995) 171-173, for his interpretation of the Egyptian symbolism in Book VII as it relates to theurgy, as well as E.C. Clarke, J. Dillon, and J.P. Hershbell (2003) xlixlii. Porphyry also refers to the solar barque in the Allegory of the Cave of the Nymphs, 10,1620 , in a passage where he stresses the importance of water as a divine substance, pointing out that the Egyptians placed superior deities on the barque, including the sun which he names specifically in the text. It should be recalled in this context that Heka, as mentioned above, is among those deities traveling on the barque. 
That specific term $\dot{\alpha} \mu \varepsilon \dot{p} \iota \sigma \tau o \varsigma$ is used several times in books VII and VIII by Iamblichus in describing this transcendent, paternal Demiurge. It may be that this usage is an indication that Iamblichus had already included in his philosophy a concept known to be fully elucidated only in later extant Neoplatonic sources such as Proclus. At the beginning of Chapter 13 of Platonic Theology V, as well as I.310.15-18 of his Timaeus Commentary, Proclus sets out four distinct levels for the Demiurgy, a doctrine however

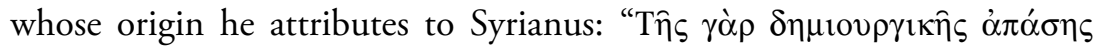

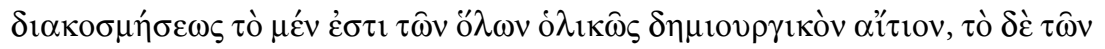

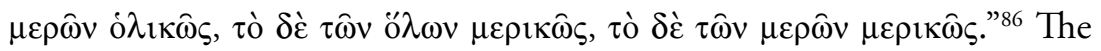
first two levels refer to the highest Demiurgy of the Timaeus, associated with the Paternal Zeus and, as shown above, Helios and Kmeph, and as the passage indicates is predicated on the key distinction of the two adverbs, ó $\lambda$ ı $\hat{\varsigma} \varsigma$ in the first two levels, and $\mu \varepsilon \rho ı \hat{\omega} \varsigma$ used in the last two. ${ }^{87}$ In summing up how the Egyptians established a view of the universe that included much more than just materialistic elements, Iamblichus at de Myst. VIII.4.267.2-6 again uses remarkably similar language to Proclus: "к $\alpha \theta \alpha \rho o ́ v$

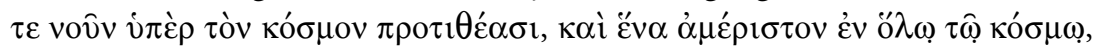

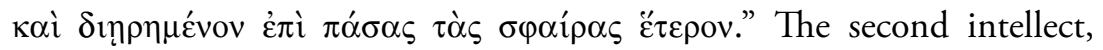

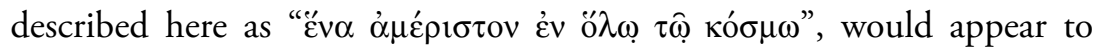
occupy the same position as Proclus' Paternal Demiurge, and the same characterization of the sun by Iamblichus in book VII as the grantor to the

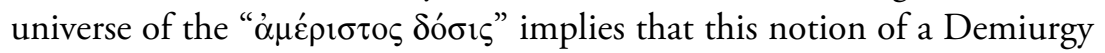
of wholes versus parts perhaps did not originate with Syrianus. Iamblichus also employs the same term in describing the solar god of the lotus and barque in VII.2 in his Demiurgic role, when he gives " $\tau \grave{\alpha} \varsigma \pi \rho \omega \tau$ ovprov̀ $\varsigma$

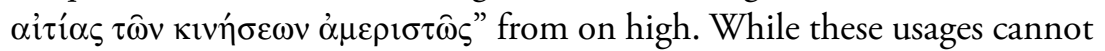
be taken as absolute proof that this differentiated Demiurgy was first established by Iamblichus rather than Syrianus, it is worth noting that the

\footnotetext{
86) In Tim. I.310.15-18, quoted in J. Opsomer (2003) 10. Cf. J. Dillon (2000) 344-345 for the four level Demiurgy. See Proclus ed. and transl. H.D. Saffrey and L.G. Westerink (1987) 170 on Syrianus as the originator of this doctrine.

87) "Disons d'abord quelques mots sur la démiurgie universelle ( $\dot{\hat{\lambda}} \mathrm{\imath} 1 \hat{\omega} \varsigma)$. Proclus affirme que la démiurgie intellective et invisible 'va de l'indivision au divisible, de l'unifié au multiple, du non-dimensional aux masses corporelles comportant toutes les dimensions," J. Opsomer (2003) 11, quoting in Tim I.370.13-16. Cf. J. Opsomer (2000) 119-121 for a similar delineation of late Neoplatonic Demiurgy.
} 
consistency of the language when discussing the Demiurgic functions of Kmeph at least raises the question that Iamblichus might have preceded Syrianus in introducing this concept.

Furthermore Iamblichus possibly alludes to yet another higher divine figure in this same passage summarizing the Egyptian view of Demiurgy in VIII.4. He includes mention of a divinity not given an Egyptian name

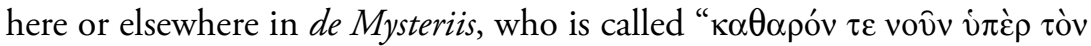

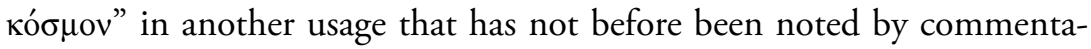

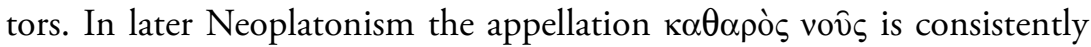
applied to the figure of the god Kronos as the Father of Demiurges, occupying the highest and first position of the triad of intellectual gods in the noeric realm of which the Paternal Zeus is the third member. Proclus provides excellent examples of Kronos in this role at Platonic Theology V.5.20.23- 21.10 and his Commentary on the Cratylus at CVII p.58.1659.8 and CX 62.27-63.6. ${ }^{88}$ But from the evidence of Fragment 1 of Iamblichus' Commentary on the Sophist, it would appear that he had already conceived of Kronos in this manner, for Iamblichus equates the Stranger in that dialogue with indeed this Father of Demiurges, whose relation to the "secondary Demiurges" Proclus defined in his Commentary on the Cratylus at CXLVIII p.83ff. ${ }^{89}$ The secondary Demiurges in the Cratylus Commentary are the Kronides Zeus, Poseidon, and Pluto, but the Zeus active at this level is not the same as the Paternal or monadic Zeus, rather he is a lower instantiation of the Olympian god. This triad of Demiurges is the same as those described by Hermias in his Commentary on the Phaedrus referred to above and is thoroughly explicated by Proclus in Book VI of his Platonic Theology on the hypercosmic gods., especially VI.8, where the difference between the first and this second Zeus is delineated. If then Iamblichus' transcendant intellect in de Myst. VIII.4 most likely relates to

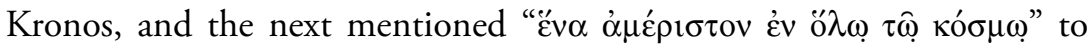
Kmeph or Helios or the Paternal Zeus, then is there any reference external to Iamblichus for the third named intellect in that passage, the one that is

\footnotetext{
88) For Kronos as highest intellectual god, see Proclus ed. and transl. H.D. Saffrey and L.G. Westerink (1987) 158, 161-162. The fact that Iamblichus posits this divine being as one clearly distinguished from Kmeph offers more evidence that Kmeph is not Kronos, as Thomas Taylor had asserted, since this separate entity, from its epithet given here, is most likely associated with Kronos.

89) For the Sophist fragment, see the commentary of J. Dillon (1973) 245-46.
} 


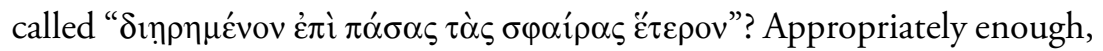
Proclus' Commentary on the Cratylus offers a possible key to revealing the identity of this intellect in once again the usage of exactly the same language: the Demiurgic triad of Zeus, Poseidon, and Pluto is characterized

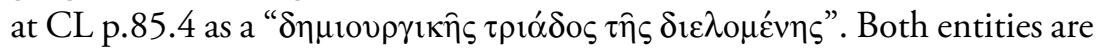

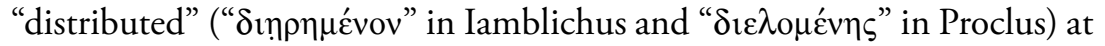
the level just below the Paternal Zeus, and Proclus goes on in that passage to point out how the second Zeus occupies the highest role in the distributed triad by means of communion with the higher and first Paternal Zeus

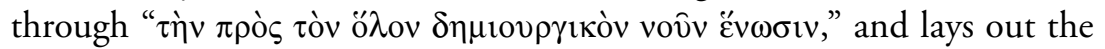
triad as one where this lower Zeus represents paternal Being, Poseidon Power or Life, and Pluto Nous, at their secondary level, embodying the well-known Neoplatonic triad of Being, Life and Intellect. ${ }^{90}$ But Iambli-

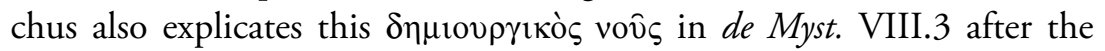
discussion of Heikton and Kmeph, where he claims that the Egyptians have gods who act as Demiurges of the visible world, just below the level of Kmeph, as the order of his presentation appears to imply, and who are the functional embodiments of that $\delta \eta \mu$ เovprıкò these as, interestingly enough, a triad of gods, Amun, Ptah, and Osiris, each contributing to the creation of the physical universe: Amun bringing to light the "hidden reason principles", Ptah "infallibly and expertly bringing to perfection each thing in accordance with the truth", and Osiris who is "productive of goods." Is it not likely that Iamblichus here is setting up an Egyptian analogue of the secondary Demiurgic triad of Zeus, Poseidon, and Pluto elaborated on by Proclus in his Commentary on the Cratylus? It would appear at least fairly clear that they hold the same position in the Demiurgy as the secondary triad in Proclus, and one can point out that there is a known association among the Greeks between Amun and Zeus, though any correspondence of the other two Egyptian gods to Poseidon and Pluto is not obvious, beyond perhaps the observation that both Osiris and Pluto are associated with judging the dead in the Underworld. ${ }^{92}$ There is no evidence in fragments of his other writings, however, that Iamblichus

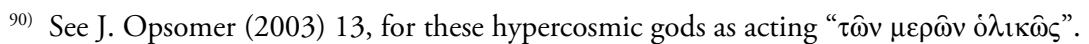

91) Translation by E.C. Clarke, J. Dillon, and J.P. Hershbell (2003) 311-312.

92) See E.C. Clarke, J. Dillon, and J.P. Hershbell (2003) 311n414, for the association of Amun and Zeus. Iamblichus' choice of Amun, Ptah, and Osiris may result merely from the fact that they are three of the most major Egyptian gods.
} 
ever posited such a triad of secondary Demiurges of Zeus, Poseidon, and Pluto or any other Hellenic gods, which however does appear later as well established within the Neoplatonic theology of Proclus. But does this triad

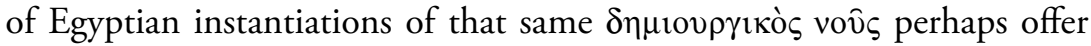
indirect evidence that Iamblichus is setting up an Egyptian counterpart to a similar triad of Hellenic gods which he might have posited more explicitly elsewhere, perhaps in his lost treatise Пврі $\Theta \varepsilon \hat{\omega} v ?^{293}$

Continuing on with other orders of Demiurgy of the visible universe, Iamblichus next expounds on what appears to be a third taxis of Egyptian gods, including four male and four female, "assigned" in de Myst. VIII.3.254.4ff to the sun, which in fact must be a reference to the Ogdoad of Hermopolis discussed above, and another sublunar Demiurgy assigned to the moon, most likely in the person of Thoth, though Iamblichus does not name him specifically. ${ }^{94}$ At this point and with the reference to zodiacal entities which comes next, Iamblichus is clearly dealing with the lowest levels of creation, and the sun which rules over the Ogdoad is likely meant here to be the visible and lowest of the instantiations of Helios, just like the visible sun as set forth by Julian in his Hymn. In the beginning of VIII.4 Iamblichus will make it clear then to Porphyry that the full-blown-and fully Neoplatonic_-system that has been set forth in these chapters of de Myst. VIII is the correct view of Egyptian religion, building apparently on that of the Hermetica, and that Porphyry has been misled by writers such as Chaeremon who have dealt only with the lower levels of existence, where Fate appears to rule all in what he saw as a fundamentally materialistic cosmos.

\footnotetext{
93) Another work of Iamblichus that is now lost might well have offered an opportunity to discuss these theological issues, the seventh book of his series on Pythagoras, the treatise on theological numbers, excerpts of which Dominic O'Meara has detected in Psellus' work "On Ethical and Theological Arithmetic". Unfortunately the relevant portion of Psellus' text containing what appears to be the theological extracts is extremely brief and terse, and no overt references are made to any named deities, but O'Meara has shown at least how similar it is in language to de Myst. VIII.2; cf. O’Meara (1989) 81-84. Most intriguing

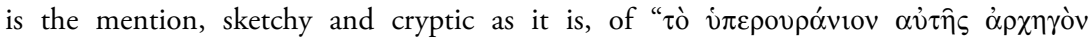
$\delta ı \alpha \kappa \sigma \mu \eta \dot{\sigma \varepsilon \omega \varsigma}$ " at line 74 of the text immediately following Psellus' description of the "intelligible and brightest monad" which ascends to the "highest cause", O'Meara (1989)

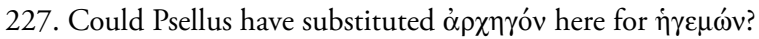

94) On the likelihood of Thoth here, see E.C. Clarke, J. Dillon, and J.P. Hershbell (2003) 313.
} 
In summary, then, the following Neoplatonic principles and theological entities can be argued to appear in Iamblichus' representation of Egyptian and Hermetic thought in de Myst. VIII: in the first taxis, the Simple One and the One Existent, in the second taxis, the One Existent in the form of Heikton, the Egyptian Heka, the noeric Paternal Demiurge, Zeus/Helios, in the form of Kmeph, the Egyptian Kematef, the noetic Father of Demiurges, Kronos, not given any Egyptian or Hellenic form, rather merely described as the "pure intellect", the secondary Demiurgic triad of Zeus, Poseidon, and Pluto, in the forms of the Egyptian Amun, Ptah, and Osiris, and finally in the third taxis, the sublunary Demiurgic gods in the form of Egyptian Ogdoad. ${ }^{95}$

Iamblichus' treatment of the Egyptian gods in the second taxis, despite the fact it includes the various Neoplatonic interpretative glosses given them as explicated above, is still cursory and all but elliptical, though elements of it point to or suggest, it would appear, a considerable number of features especially at the noeric level of the complex of notions regarding Demiurgy known definitively only from later Neoplatonism. The sketchy nature of this brief excursus on Egyptian religion, whose chief purpose, it appears, is to convince Porphyry that not only are the Egyptians' beliefs non-materialistic but indeed also show themselves to be thoroughly Neoplatonic, with their own divine elements in the realm of the One and the noetic-noeric realm, even structured along the lines of Iamblichus' own particular system of first principles. If the similarities outlined above as detected by inferences drawn between his Neoplatonic characterizations of the cited Egyptian gods and concepts detailed in passages from other later Neoplatonists illustrating known elements of their theology are correct, then is it not possible that Iamblichus was drawing examples for Porphyry's education in these chapters of de Mysteriis that might even be seen as a breviary, Egyptian version of his lost $\Pi \varepsilon \rho i$ i $\Theta \varepsilon \hat{\omega} v$, in which the Hellenic gods would have likely been given the same treatment, and so might not their Neoplatonic hierarchy be even more like that found in Proclus' theology than previously has been thought? The evidence offered in this analysis of de Myst. VIII is admittedly highly inferential and indeed at best tentative, given the nature of the text and especially the fact that Iamblichus, to

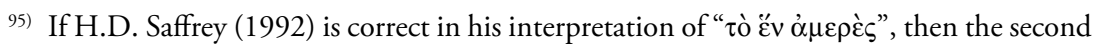
taxis also includes an entity most probably identified with the Simple One. 
be sure, is delineating here an Egyptian system and not an overtly Hellenic one. But the evidence is certainly intriguing, and without the benefit of more detailed information about his Hermetic sources and of course the primary evidence of his Commentary on the Chaldaean Oracles and the $\Pi \varepsilon \rho i \mathrm{i} \varepsilon \hat{\omega} v$, at most this type of analysis, inferential and provisory as it is, will likely remain the best type effort possible.

\section{Bibliography}

Anonymous, Prolégomènes a la philosophie de Platon, edited and translated by L.G. Westerink and J. Trouillard with the collaboration of A.-Ph. Segonds (Collection des Universités de France), Paris: Les Belles Lettres, 1990.

Assmann, Jan, The Search for God in Ancient Egypt, translated by David Lorton, Ithaca: Cornell University Press, 2001.

Bonnet, Hans, Lexikon der ägyptischen Religionsgeschichte, Hamburg: Nikol Verlagsgesellschaft, 2000.

Brisson, Luc, "La figure de Chronos dans la théogonie orphique et ses antécédents iraniens" in Orphée et l'Orphisme dans l'Antiquité gréco-romaine, Aldershot: Variorum, 1995: 37-55.

Copenhaver, Brian P., Hermetica: The Greek Corpus Hermeticum and the Latin Asclepius in a New English Translation, Cambridge: Cambridge University Press, 1992.

Courcelle, Pierre, Late Latin Writers and their Greek Sources translated by Harry E. Wedeck, Cambridge, MA: Harvard University Press, 1969.

Cumont, Franz, "La Théologie solaire du paganisme romain”, Mémoires présentés par divers savants à l'AIBL ( extrait du T.XII, 2 ), 1911: 447-479.

Damascius, The Philosophical History edited and translated by Polymnia Athanassiadi, Athens: Apamea, 1999.

- Traité des premiers principes vol. III, edited and translated by L.G. Westerink, J. Combès, and A.-Ph. Segonds (Collection des Universités de France), Paris: Les Belles Lettres, 1991.

Deuse, Werner, "Der Demiurg bei Porphyrios und Jamblich" in Die Philosophie des Neuplatonismus, Darmstadt: Wissenschaftliche Buchgesellschaft, 1977: 238-278.

Dillon, John, Iamblichi Chalcidensis in Platonis dialogos commentariorum fragmenta. Edited with translation and commentary by John M. Dillon, Leiden: Brill, 1973.

—, "Iamblichus of Chalcis" ANRW II.36.2 (1987), 862-909.

- "Porphyry and Iamblichus in Proclus' Commentary on the Parmenides" in Gonimos: Neoplatonic and Byzantine Studies Presented to Leendert G. Westerink at 75, edited by J. Duffy and J. Peradotto, Buffalo: Arethusa, 1988: 21-48.

—, The Middle Platonists revised edition, Bristol: Duckworth, 1996.

- The Great Tradition, Aldershot: Ashgate, 1997.

—, "The Role of the Demiurge in the Platonic Theology" in Proclus et la Théologie Platonicienne. Actes du Colloque International de Louvain (13-16 mai 1998). En l'honneur de 
H.D. Saffrey et L.G. Westerink (Ancient and medieval philosophy, Series 1, 26), Leuven: Leuven University Press, 2000.

—, "The Theology of Julian's Hymn to King Helios", Itaca: Quaderns Catalans de Cultura Clàssica 14-15, 1999: 103-115.

Dodds, E.R., "New Light on the "Chaldaean Oracles" in Lewy (1978).

Fauth, Wolfgang, Helios Megistos, Leiden: Brill, 1995.

Festugière, A.J., "L'expérience religieuse du médecin Thessalos" in Hermétisme et mystique païenne, Paris: Aubier-Montaigne, 1967a.

- "Les dieux ousiarques de l'Asclépius" in Hermétisme et mystique païenne, Paris: Aubier-Montaigne, 1967b.

—, La revelation d'Hermès Trismégiste vol. IV, Paris: Les Belles Lettres, 1990.

Finamore, John, Iamblichus and the Theory of the Vehicle of the Soul, American Classical Studies 14, Chico: Scholars Press, 1985.

—., "Iamblichus, the Sethians, and Marsanes" in Gnosticism and Later Neoplatonism Themes, Figures, and Texts, edited by J.D. Turner and R. Majercik, Atlanta: Society of Biblical Literature, 2000: 225-257.

Fowden, Garth, The Egyptian Hermes, Princeton: Princeton University Press, 1993.

Frankfort, Henri, Ancient Egyptian Religion, New York: Harper and Row, 1948.

Gersh, Stephen, Middle Platonism and Neoplatonism, vol. II, Notre Dame: University of Notre Dame Press, 1986.

- "Theological Doctrines of the Latin Asclepius" in Neoplatonism and Gnosticism, edited by R.T. Wallis and J. Bregman, Albany: State University of New York Press, 1992: 129-166.

Griffiths, J.Gwyn, Plutarch's De Iside et Osiride, Cardiff: University of Wales Press, 1970.

Hadot, Ilsetraut, Studies on the Neoplatonist Hierocles translated by Michael Chase, Transactions of the American Philosophical Society vol. 94 Part 1, Philadelphia: American Philosophical Society, 2004.

Hadot, Pierre, Porphyre et Victorinus I, Paris: Institut d'Études augustiniennes, 1968.

van der Horst, Pieter Willem, Chaeremon Egyptian Priest and Stoic Philosopher, Leiden: Brill, 1987.

Iamblichus, On the Mysteries, translated by Emma C. Clarke, John Dillon, and Jackson P. Hershbell, Atlanta: Society of Biblical Literature, 2003.

_- Les mystères d'Égypte [par] Jamblique, edited and translated by Édouard des Places, Paris: Les Belles Lettres, 1966.

—, On the Mysteries and Life of Pythagoras, translated by Thomas Taylor, Chippenham: The Prometheus Trust, 1999.

Jasnow, Richard and Karl-Th. Zauzich, The Ancient Egyptian Book of Thoth I, Wiesbaden: Harrassowitz Verlag, 2005.

Julian, The Works of the Emperor Julian; Orations and Letter, translated by W.C. Wright, vol. I Loeb Classical Library, Cambridge, MA: Harvard University Press, 1980.

Leisegang, Hans, "The Mystery of the Serpent" in The Mysteries Papers from the Eranos Yearbooks, Bollingen Series XXX vol. 2, Princeton: Princeton University Press, 1955: 194-260.

Lewy, Hans, Chaldaean Oracles and Theurgy: Mysticism, Magic and Platonism in the later Roman Empire, new edition by M. Tardieu, Paris: Études augustiniennes, 1978. 
Mahé, Jean-Pierre, Hermès en Haute-Egypte: les textes hermétiques de Nag Hammadi et leurs paralleles grecs et latins I, Quebec: Les Presses de l'Université Laval, 1978.

Majercik, Ruth, The Chaldaean Oracles Text, Translation, and Commentary, Leiden: Brill, 1989.

Mendel, Daniela, Die kosmogonischen Inschriften in der Barkenkapelle des Chonstempels von Karnak, Turnhout: Brépols, 2003.

O’Meara, Dominic J., Pythagoras Revived. Mathematics and Philosophy in Late Antiquity, Oxford: Clarendon Press, 1989.

Olympiodorus, Commentary on Plato's Gorgias, translated by Robin Jackson, Kimon Lycos, and Harold Tarrant, Leiden: Brill, 1998.

Opsomer, Jan, "Proclus on demiurgy and Procession: a Neoplatonic reading of the Timaeus" in Reason and Necessity. Essays on Plato's Timaeus edited by M. R. Wright, London: Duckworth and the Classical Press of Wales, 2000: 113-143.

_- "La démiurgie des jeunes dieux selon Proclus", Les Études Classiques 71 (2003), 5-49.

_- "A Craftsman and his Handmaiden. Demiurgy According to Plotinus" in Platons Timaios als Grundtext der Kosmologie in Spätantike, Mittelalter und Renaissance. Plato's Timaeus and the Foundations of Cosmology in Late Antiquity, the Middle Ages and Renaissance edited by Thomas Leinkauf and Carlos Steel, Ancient and Medieval Philosophy. De Wulf Mansion Centre, Series 1, 34, Leuven: Leuven University Press, 2005: 67-102.

Oréal, Elsa, "HÉKA, proton mageuma: une explication de Jamblique, De Mysteriis VIII, 3", Revue d'Égyptologie 54 (2003), 279-285.

des Places, Édouard, "La Religion de Jamblique" in De Jamblique à Proclus, Entretiens sur l'Antiquité Classique, tome XXI: Fondation Hardt, Geneva, 1975.

Porphyry, On Abstinence from Killing Animals, translated by Gillian Clark, Ithaca: Cornell University Press, 2000.

Proclus, The Elements of Theology, edited and translated by E.R. Dodds, Oxford: Oxford University Press, 1963.

- Théologie platonicienne vol. V, edited and translated by H.D. Saffrey and L.G. Westerink (Collection des Universités de France), Paris: Les Belles Lettres, 1987.

—, Théologie platonicienne vol. VI, edited and translated by H.D. Saffrey and L.G. Westerink (Collection des Universités de France), Paris: Les Belles Lettres, 1997.

—, Hymns translated by R.M. van den Berg, (Leiden: Brill), 2001.

Ritner, Robert K., The Mechanics of Ancient Egyptian Magical Practice, Chicago: University of Chicago Press, 1993.

"Egyptian Magical Practice under the Roman Empire: the Demotic pells and their Religious Context”, ANRW II, 18.5 (1995): 3333-3379.

Rundle-Clark, R.T., Myth and Symbol in Ancient Egypt, London: Thames and Hudson, 1959.

Sauneron, Serge, Esna vol. 5, Cairo: Institut français d'archéologie orientale du Caire, 1962.

Saffrey, H.D., "Abamon, pseudonyme de Jamblique", in Philomathes. Studies and Essays in the Humanities in Memory of Philip Merlan, edited by Robert B Palmer and Robert Hamerton-Kelly, The Hague: Martinus Nijhoff, 1971, 227-239. 
, "Relecture de Jamblique, De mysteriis, VIII, chap. 1-5" in Platonism in Late Antiquity, Hommages Père Edouard des Places, edited by S. Gersh and Ch. Kannengiesser, Notre Dame: University of Notre Dame Press, 1992, 157-171.

Sambursky, S. and Pines, S., The Concept of Time in Late Neoplatonism, Jerusalem: Israel Academy of Sciences and Humanities, 1971.

Scott, Walter, Hermetica vol. IV, Boston: Shambhala, 1985.

Sethe, Kurt, "Amun und die Acht Urgötter von Hermopolis. Eine Untersuchung über Ursprung und Wesen des ägyptischen Götterkönigs", Abhandlungen der Preussischen Akademie der Wissenschaften 4 (1929).

Shaw, Gregory, Theurgy and the Soul: The Neoplatonism of Iamblichus, University Park: Penn State University Press, 1995.

Shupak, Nili, "Where can Wisdom be Found? The Sage's Language in the Bible and in Ancient Egyptian Literature", Orbis Biblicus et Orientalis 130 (1993).

Smith, Rowland, Julian's Gods, London: Routledge, 1995.

Sodano, A.R., Giamblico. I misteri egiziani, Milan: Rusconi, 1984.

Siorvanes, Lucas, Proclus Neo-Platonic Philosophy and Science, New Haven: Yale University Press, 1996.

Strange, Steven K., "Porphyry and Plotinus' Metaphysics" in Studies on Porphyry ed. G. Karamanolis and A. Sheppard, Bulletin of the Institute of Classical Studies Supplementary Volume 98, London, 2007: 17-34.

Thissen, Heinz J., “КМНФ Ein verkannter Gott”, Zeitschrift für Papyrologie und Epigraphik, 112 (1996): 153-160.

Ulansey, David, "Mithras and the Hypercosmic Sun" in Studies in Mithraism, Rome, 1994: 257-264.

West, M.L., The Orphic Poems, Oxford: Clarendon Press, 1983.

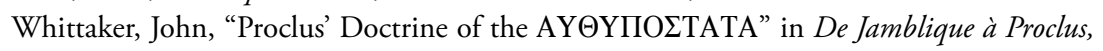
Entretiens sur l'Antiquité Classique, vol. XXI, Geneva: Fondation Hardt, 1975: 193-230.

—, "Self-Generating Principles in Second-Century Gnostic Systems" in The Rediscovery of Gnosticism I: The School of Valentinus, Leiden, 1980: 176-193.

Witt, Rex E., "Iamblichus as a Forerunner of Julian" in De Jamblique à Proclus, Entretiens sur l'Antiquité Classique, vol. XXI, Geneva: Fondation Hardt, 1975: 35-68. 